\title{
2
}

\section{Pelagic Fishing in the Mariana Archipelago: From the Prehistoric Period to the Present}

\author{
Judith R. Amesbury, Micronesian Archaeological Research Services, Guam
}

\section{Introduction}

The Mariana Islands lie between $13^{\circ}$ and $21^{\circ}$ north latitude at about $145^{\circ}$ east longitude (Figure 1 ). The geological division of the Mariana Archipelago is not the same as the political division. Politically there are two entities: Guam, which is an unincorporated territory of the United States, and the Commonwealth of the Northern Mariana Islands (CNMI), which comprises the fourteen islands north of Guam. Geologically there are two island arcs. The southern arc includes the six islands from Guam to Farallon de Medinilla, while the northern arc includes the nine islands from Anatahan to Uracas.

The southern arc islands, which began to form about 43 million years ago (Randall 1995), are older and larger than the islands of the northern arc. They are raised limestone islands with volcanic cores and well developed reef flats and coral reefs. The southern arc islands are much more densely inhabited (more than 224,000 people in the 2000 census), and according to one survey they have nearly twice as many species of fishes as the northern arc islands (Donaldson et al. 1994).

The northern arc islands are younger, smaller, high volcanic islands with steep slopes and limited coral development. They are still volcanically active. Pagan erupted in 1981, and Anatahan began to erupt in 2003 (Figure 2). The northern arc islands are sparsely inhabited (6 people in the 2000 census) and have fewer species of fishes than the southern arc islands (Donaldson et al. 1994).

\section{Prehistoric Period}

People have lived in the Mariana Islands for at least 3,500 years or about 3,000 years before European contact. The Prehistoric Period lasted from the arrival of the first people by at least $1500 \mathrm{BC}$ until the arrival of Magellan in AD 1521. Spoehr (1957) divided the long Prehistoric Period into the PreLatte Phase and Latte Phase (Figure 3). Subsequent authors (Craib 1990; Moore 1983; Moore and Hunter-Anderson 1999) have proposed various subdivisions of the Pre-Latte Phase.

Pre-Latte Phase cultural deposits are found below the surface usually along the coasts. Artefacts that characterise the Pre-Latte Phase include pottery sherds with red-slipped exterior surfaces, some of which are decorated with lime-filled designs, stone and shell tools, and beads and bracelets made from cone shells. 


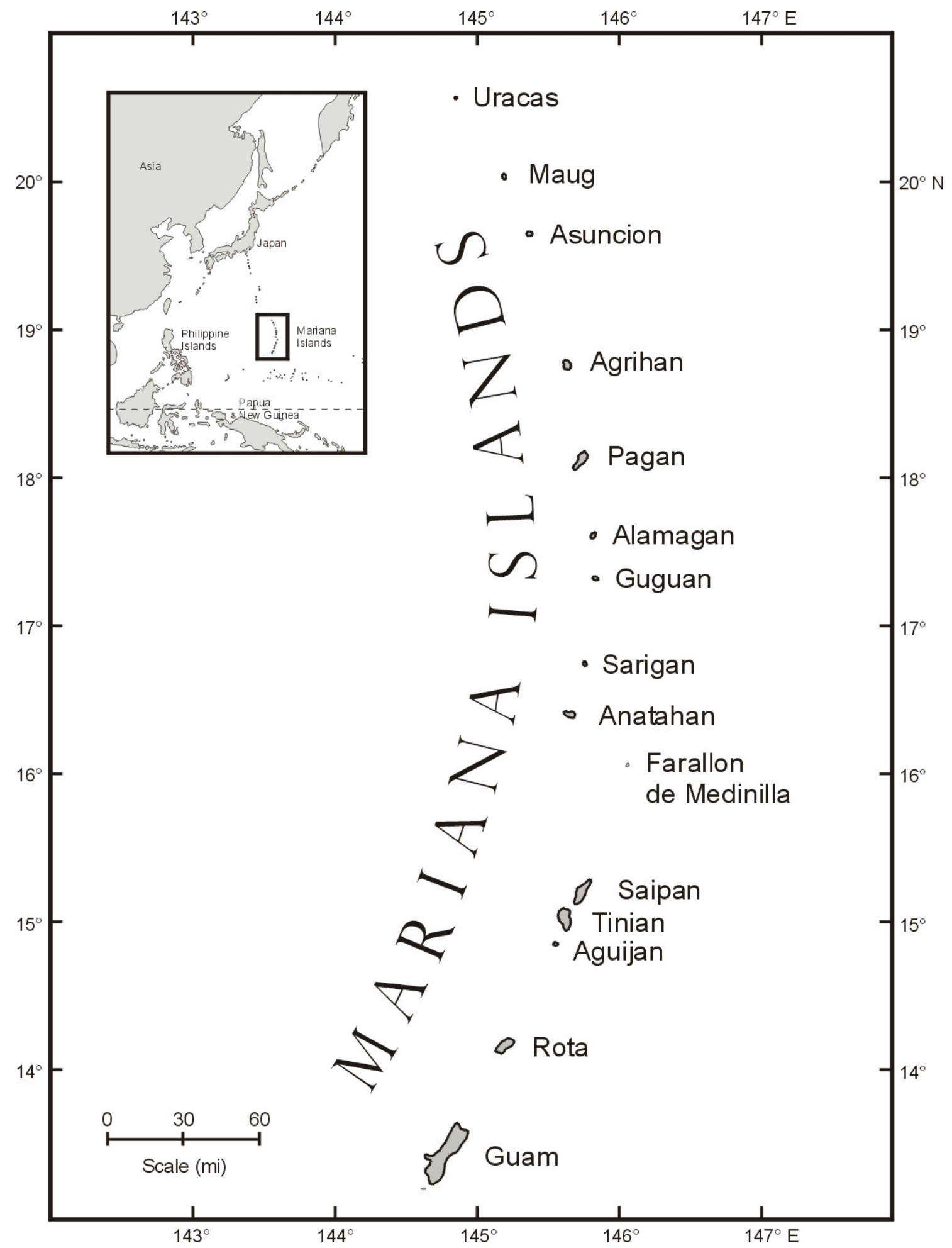

Figure 1. Mariana Islands.

Source: Map courtesy of Barry Smith. 


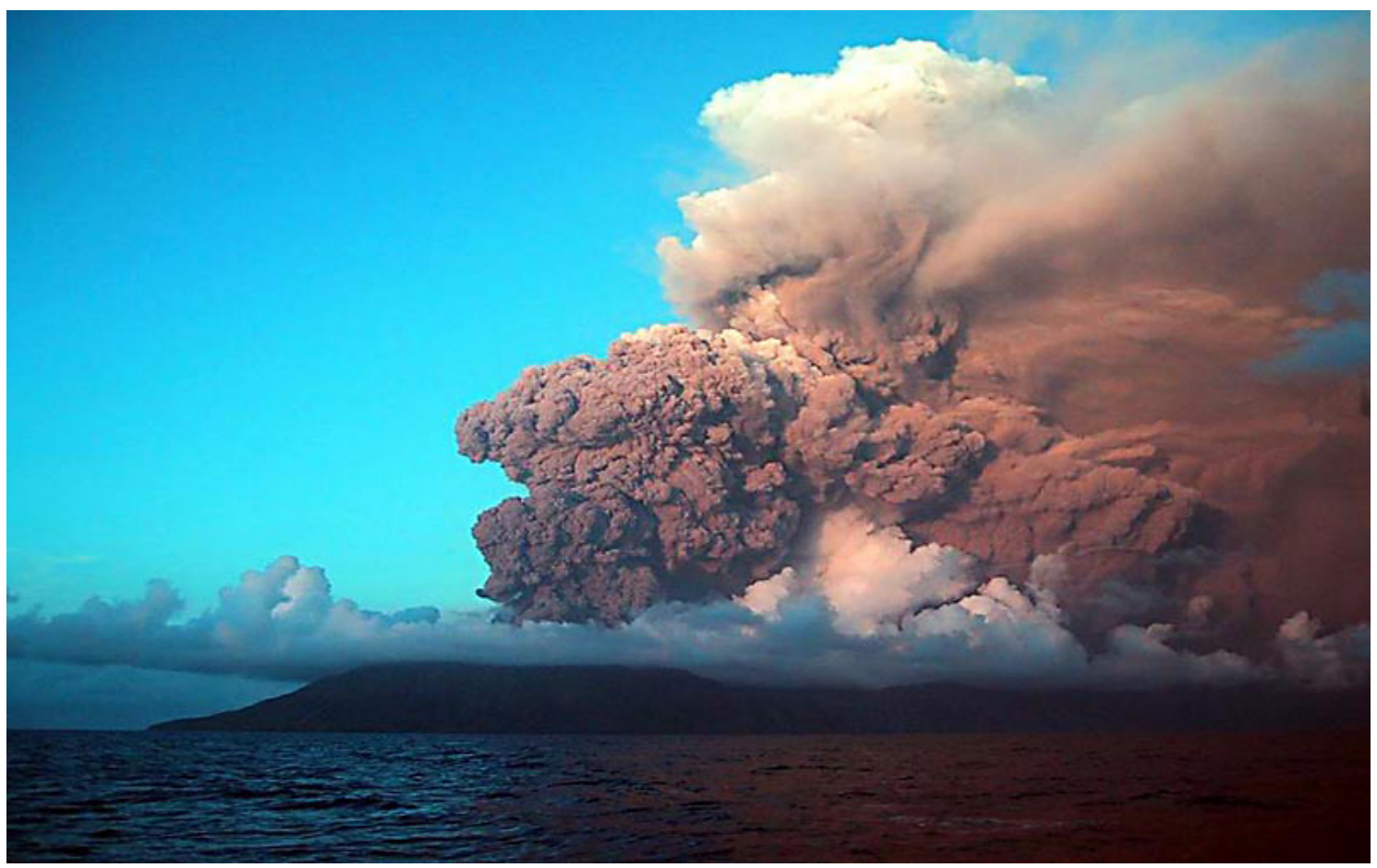

Figure 2. Anatahan erupting on May 11, 2003.

Source: Photo by Allan Sauter.

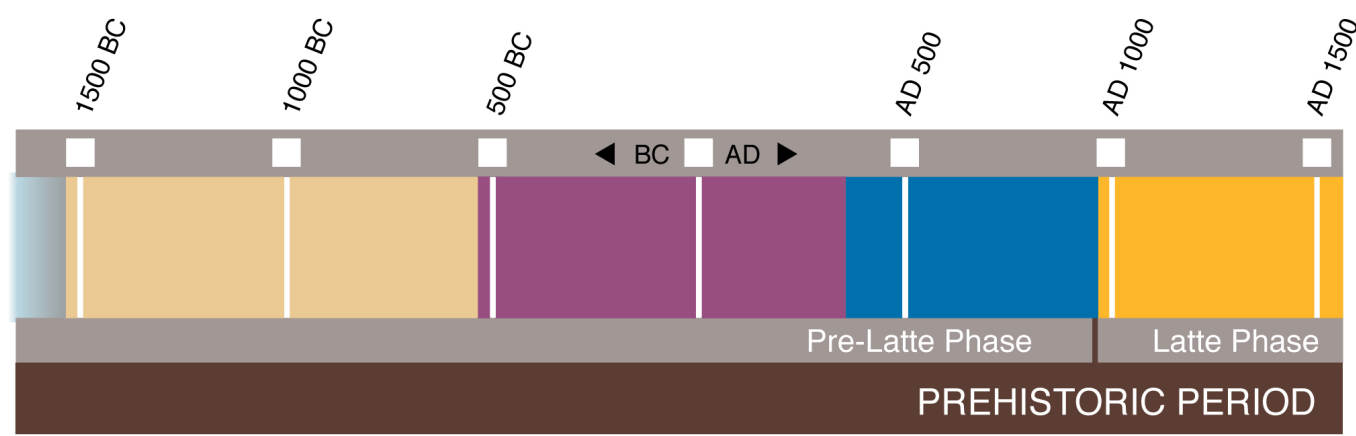

Early Pre-Latte Phase (1550-550 BC)

Intermediate Pre-Latte Phase (550 BC-AD 350)
Transitional Phase (AD 350-950)
Latte Phase (AD 950-1521)

Figure 3. Timeline of the Prehistoric Period in Guam and the CNMI showing Spoehr's (1957) broad phases of Marianas prehistory as subdivided by Moore and Hunter-Anderson (1999).

Source: Figure by Robert Amesbury.

The Latte Phase began by at least AD 1000 and is characterised by the megalithic features called latte sets. A latte set consists of two parallel rows of upright stone shafts (haligi in Chamorro) associated with capstones (tasa) (Figure 4). The number of shafts in a set varies, but sets with eight, ten, or twelve shafts are common (Graves 1986; Hunter-Anderson and Moore 2002). 
Based on the cultural materials and features associated with latte sets, archaeologists believe they functioned as foundations for residential structures. Latte Phase sites are widely distributed along the coastline as well as in the interior of the Mariana Islands. They are found not only on the major islands of the southern arc, but on the smaller islands of the northern arc as well. Characteristic artefacts of the Latte Phase include plain pottery sherds, stone mortars, stone and shell tools, and beads made from Spondylus shells.

During the Prehistoric Period the inhabitants of the Mariana Archipelago, who are now known as the Chamorro, were in contact with one another. There is evidence that all the islands shared the same culture and language (Reinman 1977; Spoehr 1957; Thompson 1932). Archaeological assemblages from the various islands are similar. It is possible that the Chamorro were also in contact with their closest Micronesian neighbors, the Refaluwasch people of the Caroline Islands to the south. The ocean-going sailing canoes of both groups would have made that possible.

When the first people arrived in the Marianas between 3,500 and 4,000 years ago, there were no large land mammals to hunt, but the ancient Chamorro had an almost unlimited supply of animal protein from the sea. They fished for both reef and pelagic (open-ocean) species and collected mollusks and other invertebrates, including crustaceans and echinoderms. They also caught sea turtles. Figure 5 shows archaeological sites on Guam with pelagic fish and turtle remains.

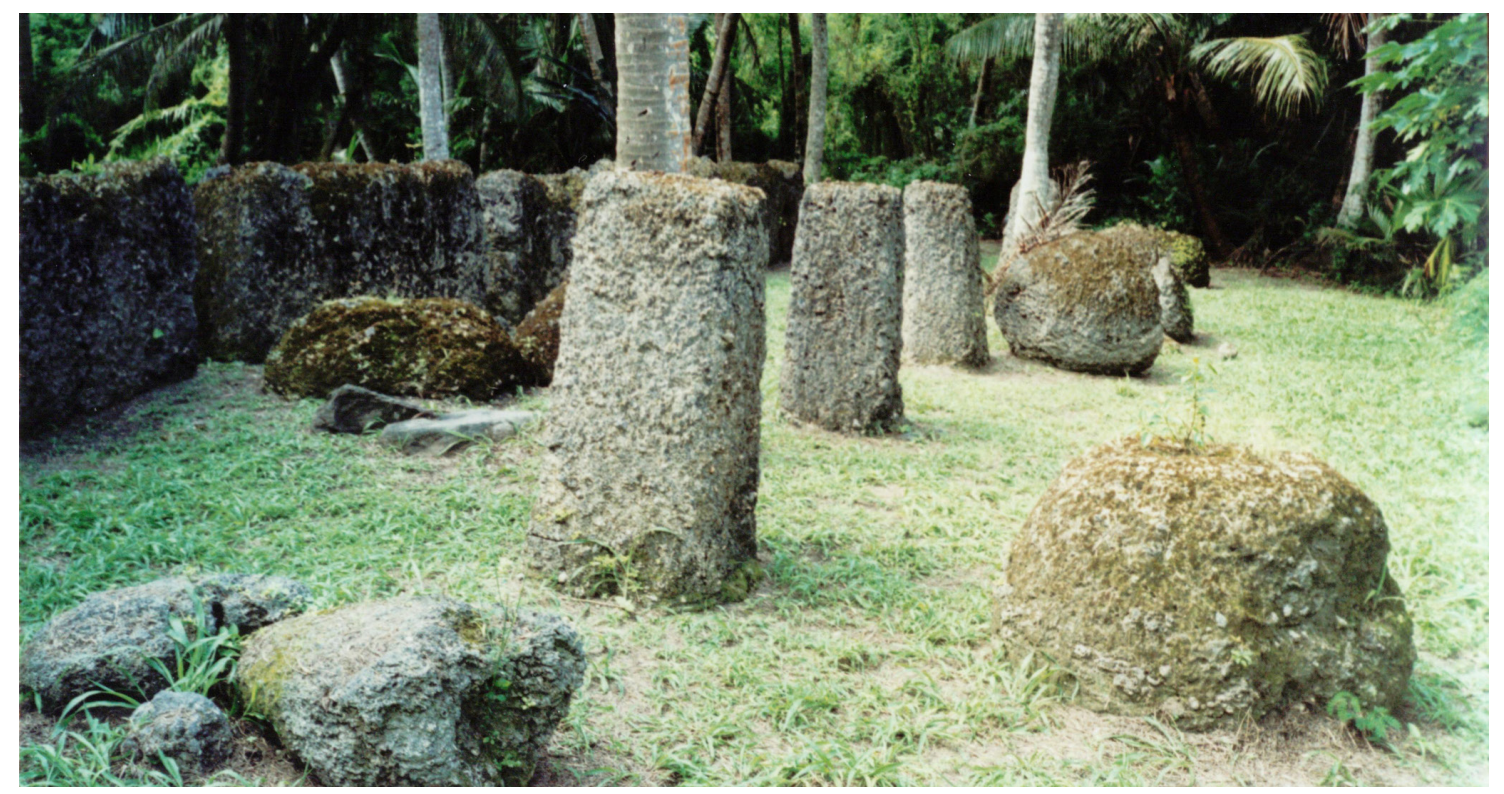

Figure 4. The "wall" latte at Mochong, Rota, with upright shafts and fallen capstones along one side and five limestone blocks along the other side.

Source: Photo by Judith Amesbury.

Faunal analysts, such as Foss Leach and Janet Davidson of the Museum of New Zealand Te Papa Tongarewa, calculate the minimum number of individuals (MNI) in archaeological fish bone collections by identifying the unique or paired bones from fishes. They attempt to determine if there were changes through time in the fishes caught. Table 1 is an example of the results of fishbone analysis. From Mangilao Golf Course Site 25, Leach and Davidson (2006a) identified 364 bones. At least 20 families or other groups are present. The minimum number of individuals is 267 . Of that number, 237 individuals were assigned to time periods based on the stratigraphy of the site and 41 radiocarbon dates. Most of the fishes date to the Intermediate and Transitional Pre-Latte Phase and the Latte Phase. No changes in the catch through time could be confirmed. 
The most abundant family in the catch from all time periods at Mangilao Golf Course is the Scaridae (parrotfishes). The large humphead parrotfish, Bolbometopon muricatum, is present throughout the Prehistoric Period. The pelagic families Coryphaenidae (mahimahi or dolphinfishes), Istiophoridae/Xiphiidae (marlins, sailfishes, and swordfishes), and Scombridae (tunas and wahoo) are also found in both Pre-Latte and Latte Phases.

The faunal analysts also suggest what methods were used for catching the fishes based on the technology of the time period, the habits and habitats of the fishes, and ethnographic comparison. Table 2 shows the likely catch methods of fishes from Mochong, Rota, a site occupied from approximately 1000 BC to AD 1700 (Craib 1990). Figure 6 shows archaeological sites on Rota with pelagic fish and turtle remains.

Table 1. Families of fishes (MNI and \% MNI) from Mangilao Golf Course Site 25 by time periods.

\begin{tabular}{|c|c|c|c|c|c|c|c|c|}
\hline \multirow[t]{2}{*}{ FAMILY OR OTHER GROUP } & \multicolumn{2}{|c|}{$\begin{array}{l}\text { EARLY PRE-LATTE } \\
\text { PHASE }\end{array}$} & \multicolumn{2}{|c|}{$\begin{array}{c}\text { INTERMEDIATE } \\
\text { \& TRANSITIONAL } \\
\text { PRE-LATTE PHASES }\end{array}$} & \multicolumn{2}{|c|}{ LATTE PHASE } & \multicolumn{2}{|c|}{ HISTORIC PERIOD } \\
\hline & MNI & $\%$ MNI & MNI & $\%$ MNI & MNI & $\%$ MNI & MNI & $\%$ MNI \\
\hline Scaridae (Parrotfishes) & 6 & 60.0 & 33 & 27.3 & 43 & 43.4 & 2 & 28.6 \\
\hline Coryphaenidae (Mahimahi ) & & & 21 & 17.4 & 18 & 18.2 & & \\
\hline Lethrinidae (Emperors) & & & 14 & 11.6 & 4 & 4.0 & 1 & 14.3 \\
\hline Coridae/Labridae (Wrasses) & & & 11 & 9.1 & 5 & 5.1 & & \\
\hline Istiophoridae/Xiphiidae (Billfishes) & & & 3 & 2.5 & 9 & 9.1 & 1 & 14.3 \\
\hline Epinephelidae (Groupers) & 1 & 10.0 & 8 & 6.6 & 2 & 2.0 & & \\
\hline Elasmobranchii (Sharks and rays) & 1 & 10.0 & 6 & 5.0 & 2 & 2.0 & 1 & 14.3 \\
\hline Balistidae (Triggerfishes) & 1 & 10.0 & 4 & 3.3 & 2 & 2.0 & & \\
\hline Diodontidae (Porcupinefishes) & & & & & 6 & 6.1 & 1 & 14.3 \\
\hline Acanthuridae (Surgeonfishes) & & & 2 & 1.7 & 2 & 2.0 & 1 & 14.3 \\
\hline Lutjanidae (Snappers) & & & 3 & 2.5 & 2 & 2.0 & & \\
\hline $\begin{array}{l}\text { Scombridae, Tribe Scomberomorini } \\
\text { (Wahoo) }\end{array}$ & & & 3 & 2.5 & 1 & 1.0 & & \\
\hline Nemipteridae (Monocle breams) & & & 3 & 2.5 & 1 & 1.0 & & \\
\hline Teleostomi (includes bony fishes) & & & 4 & 3.3 & & & & \\
\hline Coridae (Wrasses) & 1 & 10.0 & 1 & 0.8 & & & & \\
\hline Scombridae, Tribe Thunnini (Tunas) & & & 2 & 1.7 & & & & \\
\hline Echeneidae (Remoras) & & & 2 & 1.7 & & & & \\
\hline Carangidae (Jacks) & & & & & 1 & 1.0 & & \\
\hline Holocentridae (Squirrelfishes) & & & 1 & 0.8 & & & & \\
\hline Kyphosidae (Sea chubs or rudderfishes) & & & & & 1 & 1.0 & & \\
\hline Total & 10 & 100.0 & 121 & 100.0 & 99 & 100.0 & 7 & 100.0 \\
\hline
\end{tabular}

Source: This table is adapted from Leach and Davidson (2006a). For confidence limits of percentages, see Leach and Davidson. Classification of tunas has been updated using Nelson (2006). 


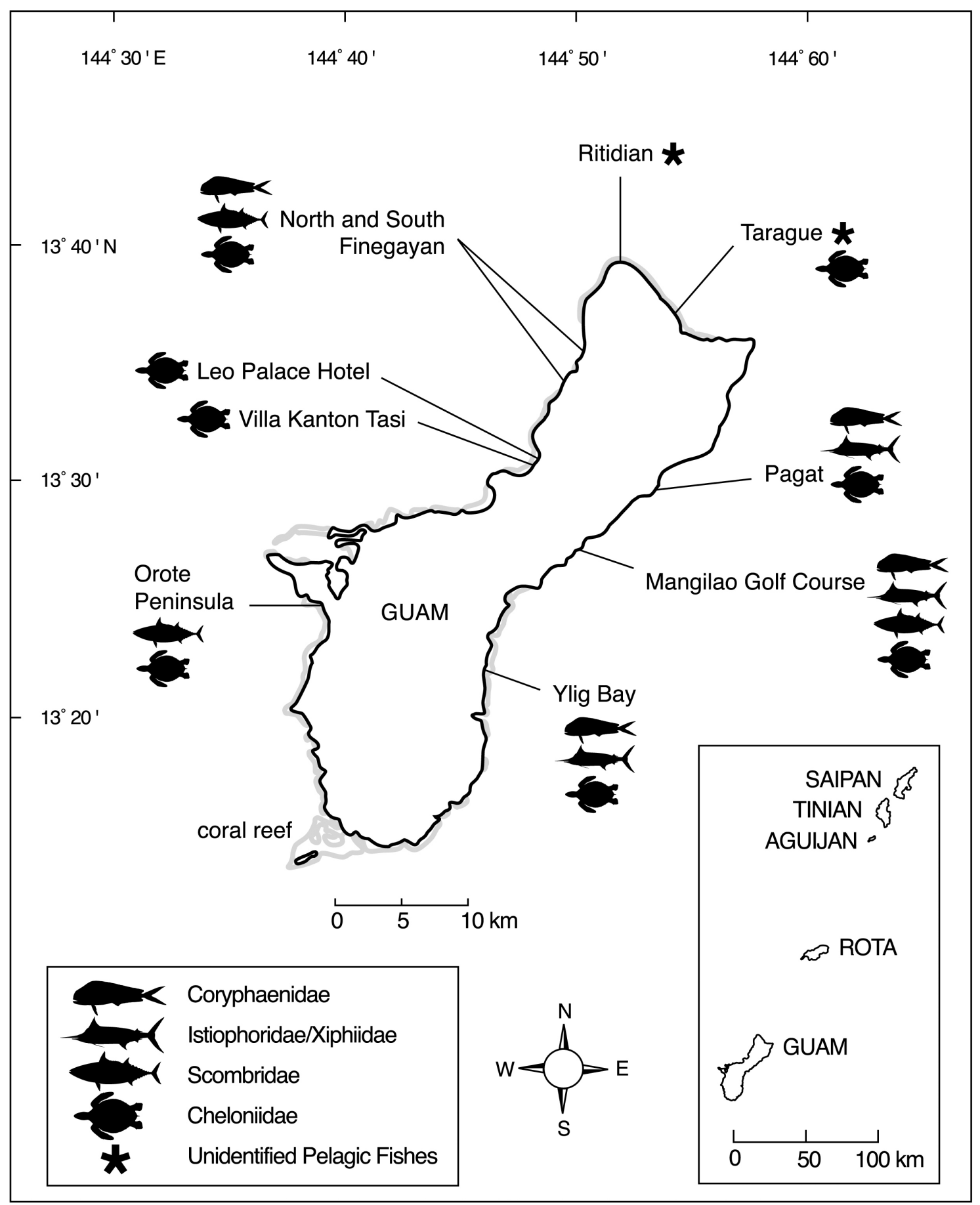

Figure 5. Guam, showing archaeological sites with pelagic fish and turtle remains.

Source: Figure by Robert Amesbury. 
Table 2. Likely catch methods of fishes from Mochong, Rota by families (MNI and \% MNI).

\begin{tabular}{|c|c|c|c|c|}
\hline LIKELY CATCH METHOD & FAMILY OR OTHER GROUP & COMMON NAME & MNI & $\%$ MNI \\
\hline \multirow[t]{6}{*}{ Netting } & & & 105 & 33.5 \\
\hline & Bothidae & Left-eyed flounders & & \\
\hline & Scaridae & Parrotfishes & & \\
\hline & Acanthuridae & Surgeonfishes & & \\
\hline & Balistidae & Triggerfishes & & \\
\hline & Aluteridae & Filefishes & & \\
\hline \multirow[t]{7}{*}{ Demersal Baited Hook } & & & 109 & 34.8 \\
\hline & Epinephelidae & Groupers & & \\
\hline & Lutjanidae & Snappers & & \\
\hline & Nemipteridae & Monocle breams & & \\
\hline & Lethrinidae & Emperors & & \\
\hline & Coridae & Wrasses & & \\
\hline & Coridae/Labridae & Wrasses & & \\
\hline \multirow[t]{5}{*}{ Pelagic Lures } & & & 51 & 16.3 \\
\hline & Scombridae, Tribe Scomberomorini & Wahoo & & \\
\hline & Coryphaenidae & Mahimahi & & \\
\hline & Carangidae & Jacks & & \\
\hline & Scombridae, Tribe Thunnini & Tunas including yellowfin and skipjack & & \\
\hline \multirow[t]{4}{*}{ Harpoons or Bait Trolling } & & & 10 & 3.2 \\
\hline & Istiophoridae & Marlins, sailfishes & & \\
\hline & Istiophoridae/Xiphiidae & Marlins, sailfishes/ & & \\
\hline & & Swordfishes & & \\
\hline \multirow[t]{7}{*}{ General Foraging } & & & 23 & 7.3 \\
\hline & Holocentridae & Squirrelfishes & & \\
\hline & Aphareidae & Snappers & & \\
\hline & Kyphosidae & Sea chubs or rudderfishes & & \\
\hline & Scorpaenidae & Scorpionfishes & & \\
\hline & Diodontidae & Porcupinefishes & & \\
\hline & Tetraodontidae & Puffers & & \\
\hline \multirow[t]{2}{*}{ Basket Traps } & & & 8 & 2.6 \\
\hline & Muraenidae & Moray eels & & \\
\hline \multirow[t]{2}{*}{ Opportunistic Catch } & & & 3 & 1.0 \\
\hline & Elasmobranchii & Sharks and rays & & \\
\hline \multirow[t]{3}{*}{ Unknown } & & & 4 & 1.3 \\
\hline & Platacidae & Batfishes & & \\
\hline & Teleostomi & Includes bony fishes & & \\
\hline TOTAL & & & 313 & 100.0 \\
\hline
\end{tabular}

Source: This table is adapted from Leach et al. $(1988,1990)$. Classification of tunas has been updated using Nelson (2006). This table is designed to reproduce information from its sources and is not a commentary on points raised in $01 \mathrm{mo}$ (this volume). 


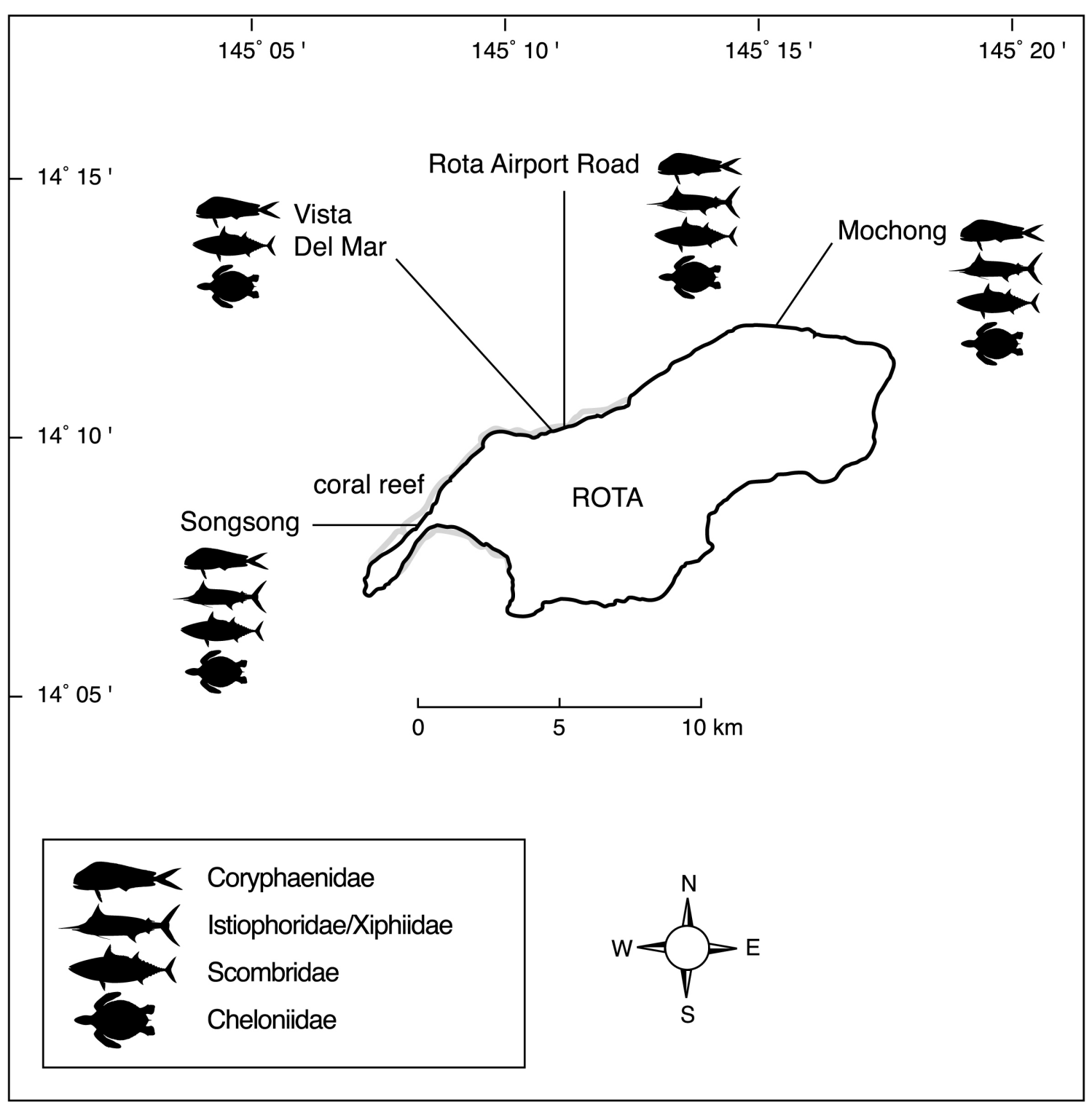

Figure 6. Rota, showing archaeological sites with pelagic fish and turtle remains.

Source: Figure by Robert Amesbury.

Ten sites in the Mariana Archipelago have MNI analysis and pelagic fish remains (Amesbury and Hunter-Anderson 2008). Percentages by MNI of pelagic fishes belonging to the families Coryphaenidae, Istiophoridae/Xiphiidae, and Scombridae are shown in Table 3. The average for the ten sites is nearly sixteen percent pelagics. Since these fishes weigh more than reef fishes, considerably more than sixteen percent of the weight of fish eaten came from pelagic species.

Mahimahi was identified at eight of the ten sites shown in Table 3. Marlin was also identified at eight of the ten sites. This is unusual for Pacific islands. The database of fish remains from archaeological sites at the Museum of New Zealand Te Papa Tongarewa contains information on more than 75 tropical Pacific island sites and more than 125 sites in New Zealand, but none of the sites outside the Marianas have mahimahi remains and only one site outside the Marianas has marlin remains (Leach and Davidson 2006b). Marlin accounted for less than one percent of the MNI at Motupore, Port Moresby, Papua New Guinea. 
Table 3. Percent of pelagic fishes in the total MNI of identified fishes from ten sites in the Mariana Islands with pelagic fish remains and $\mathrm{MNI}$ analysis.

\begin{tabular}{lrrrr}
\hline SITE OR AREA & CORYPHAENIDAE \% MNI & ISTIOPHORIDAE/XIPHIIDAE \% MNI & SCOMBRIDAE \% MNI & ALL PELAGICS \% MNI \\
\hline Pagat, Guam & 4.0 & 1.0 & & 5.0 \\
Mangilao, Guam & 15.4 & 5.2 & 2.3 & 22.9 \\
Ylig Bay, Guam & 38.9 & 4.2 & 2.6 & 43.1 \\
Afetña, Saipan & & & & 2.6 \\
Unai Masalok, Tinian & 2.2 & & 1.3 & 2.2 \\
Tachogna, Tinian & 0.7 & 1.3 & 1.9 & 3.3 \\
Mochong, Rota & 11.8 & 3.2 & 8.1 & 16.9 \\
Airport Road, Rota & 16.3 & 9.2 & 11.5 & 33.6 \\
Vista Del Mar, Rota & & 7.7 & 1.2 & 19.2 \\
Songsong, Rota & 4.7 & 3.5 & & 9.4 \\
\hline
\end{tabular}

Source: This table is adapted from Amesbury and Hunter-Anderson (2008).

However, there is another part of the Pacific with evidence of pre-contact fishing for mahimahi and marlin. This is the area on either side of the Luzon Strait that includes southern Taiwan and the northern Philippines. Coryphaenidae and Istiophoridae are among the most common taxa from archaeological sites at Eluanbi on the southern coast of Taiwan, which date to approximately the same time period as the early Pre-Latte Phase in the Marianas or somewhat earlier (Li 1997, 2002). Across the Luzon Strait from Taiwan in the Batanes Islands of the Philippines, mahimahi bones have been recovered from the Savidug Dune Site dating back to at least 3500 years ago (Campos 2009). The Yami of Botel Tobago, an island off the southeast coast of Taiwan, traditionally fished for mahimahi (Hsu 1982; Kano and Segawa 1956). (Also see Hashimura, this volume, for evidence of pelagic fishing in prehistoric Japan.)

Leach and Davidson (2000, 2006a) noted that people in both southern Taiwan and the Marianas possessed highly specialised fishing skills not seen in other parts of Oceania. Pelagic fishing skills may be one of the pieces of the puzzle that will help to answer the question of where the people of the Marianas came from.

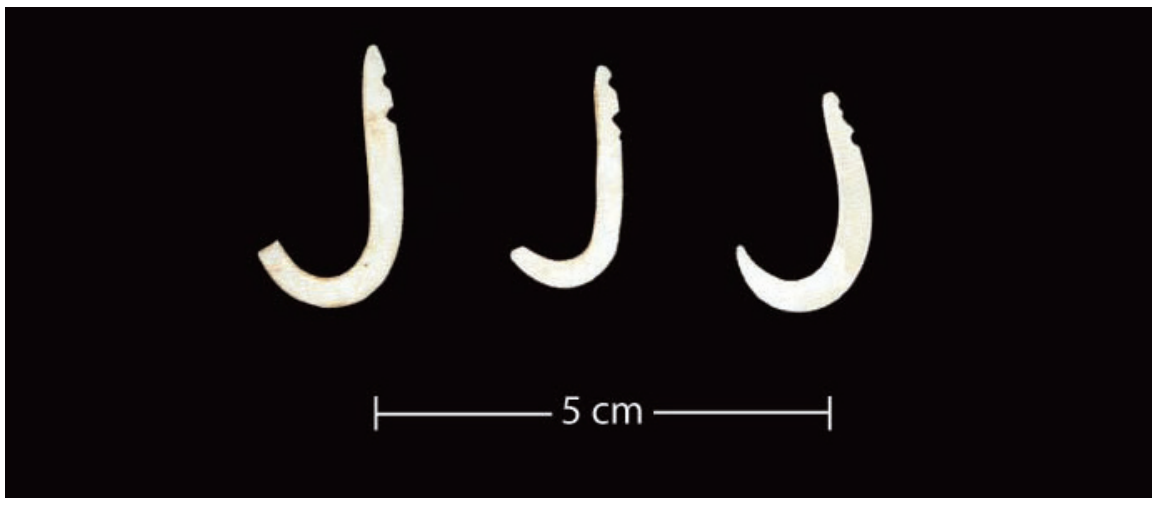

Figure 7. J-shaped fishhooks made from Isognomon shell recovered from Villa Kanton Tasi, Tumon Bay, Guam.

Source: Photo by Frank Wells. 


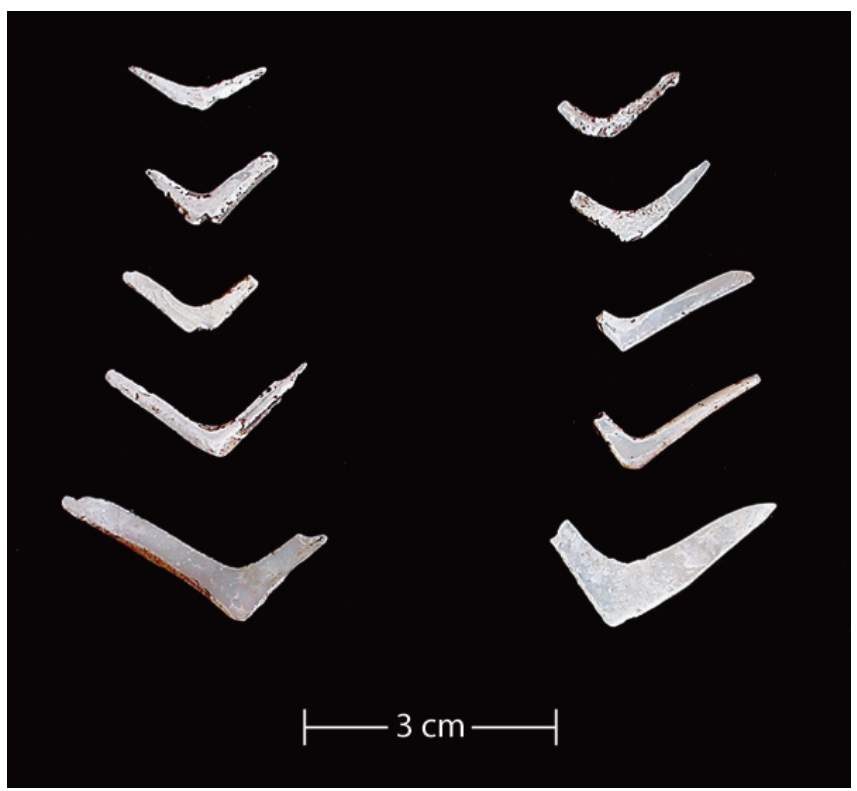

Figure 8. Isognomon gorges and gorge fragments from the Mangilao Golf Course site, Guam.

Source: Photo by Frank Wells.

In addition to the actual fish remains, archaeologists find pieces of fishing gear from the Prehistoric Period. Most abundant are one-piece J-shaped fishhooks (Figure 7) and V-shaped gorges (Figure 8) made of Isognomon shell. Points (Figures 9, 10) of composite fishhooks are more commonly found than the shanks, which may have been made of more perishable materials. Human bone spear points were used in fighting, but may have been used as harpoons as well (Figure 11).

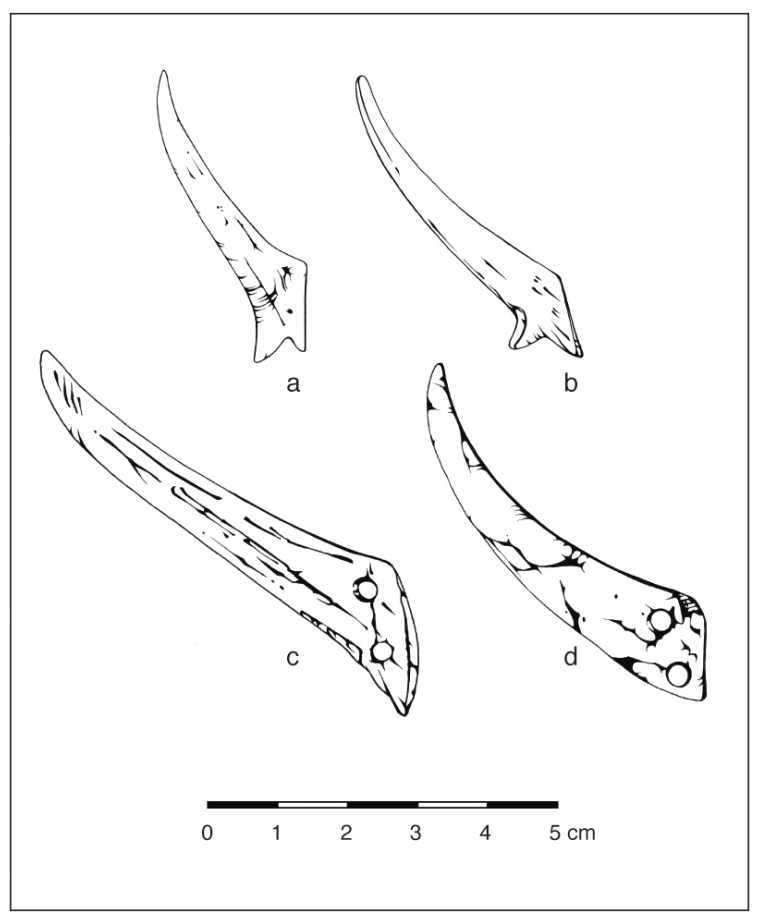

Figure 9. Points of composite fishhooks from archaeological sites in Guam. $a=$ human bone point from Tarague (Ray 1981); $b$ and c = bone points from Pagat (Craib 1986); $d$ = shell point from Pugua Point, North Finegayan. 


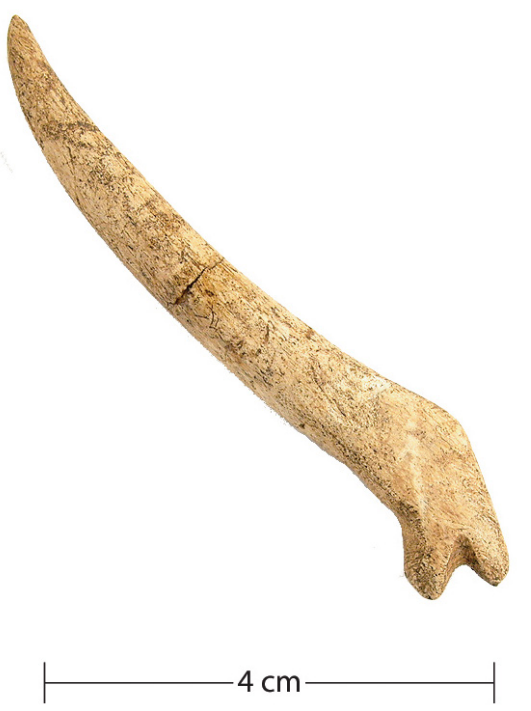

Figure 10. Human bone point of composite fishhook from Ylig Bay, Guam.

Source: Photo by Rick Schaefer.

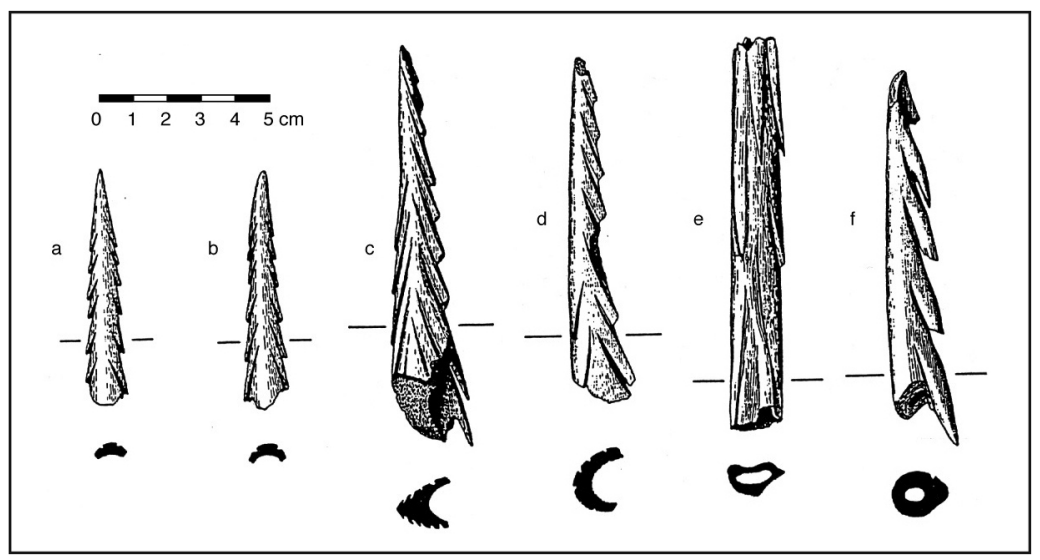

Figure 11. Human bone spear points found in association with Burial 6 at Afetña, Saipan.

Source: from McGovern-Wilson 1989.

\section{Historic Period}

In contrast to the long Prehistoric Period, the Historic Period has lasted less than 500 years from European contact until the present (Table 4). Both Guam and the CNMI belonged to Spain for more than 375 years. Twentieth century colonizers include the U.S., Germany and Japan.

Table 4. The Historic Periods in Guam and CNMI.

\begin{tabular}{ll}
\hline GUAM & CNMI \\
\hline Spanish Period (AD 1521 - 1898) & Spanish Period (AD 1521 - 1899) \\
First American Period (1898 - 1941) & German Period (1899 - 1914) \\
Japanese Period (1941 - 1944) & Japanese Period (1914 - 1944) \\
Second American Period (1944 - present) & American Period (1944 - present) \\
\hline
\end{tabular}

Source: Table by Judith Amesbury. 


\section{(1) Spanish Period}

Magellan arrived at Guam in 1521, and Legazpi claimed the Mariana Islands for Spain in 1565. In that same year, the Manila galleons began sailing between Acapulco and Manila, stopping in the Marianas on their way west. It was not until 1668 that the Spanish colonised Guam. During the 147-year period between 1521 and 1668, the principal change in fishing technology was due to the introduction of iron used for fishhooks. Much more radical changes in the culture took place in the remaining 230 years of the Spanish Period.

The authors of the earliest written records pertaining to the Marianas all remarked on the exceptional sailing and fishing skills of the Chamorro. Magellan's historian, Antonio Pigafetta, said, "The pastime of the men and women of the said place, and their sport, is to go with their canoes to catch some of these flying fish with some fish-hooks made of fish bones (Lévesque 1992:200-202).

A Spaniard named Sancho, who survived the shipwreck of the Santa Margarita in 1601 and became the servant of a Chamorro named Suñama at Pago, Guam, visited another Spaniard, Fray Juan Pobre de Zamora, in Rota in 1602. Fray Juan Pobre recorded what Sancho had to say about how the Chamorro fished for flying fish and used flying fish as bait for mahimahi, billfish, and other large fishes.

When they fish for these flying-fish, those from one town all come together in a bunch and they go out in their canoes, each one with from ten to twelve gourds; to each gourd is tied with a very slim cord a small two-pointed shell hook [probably an Isognomon gorge]. One hook is baited with coconut meat and the other with shrimp or some minnow from the sea. All the fishermen throw these gourds into the sea together, everyone taking care of his own. It is by watching the gourds and seeing them wiggle that they know they have a flying-fish. There are so many fishermen because all those living on the coast of all the islands are fishermen. There are flying-fish for all of them as there are sardines in Spain. The average fish measures about one palm in length, and others about two. The first flying-fish they catch, they then eat it raw. The second one is placed as a bait on a large hook and the cord is thrown over the poop and in this manner they usually catch many dorados [mahimahi], swordfish, and other big fishes. (Lévesque 1993:176, brackets added by Amesbury).

Sancho also told the following fish story about his master Suñama to Fray Juan Pobre. Suñama caught a flying fish and ate the first one raw. With the second flying fish, he baited his hook and hooked a very large billfish (probably a blue marlin) and spent a great deal of time playing the fish to tire it. A large shark came and seized the billfish. When Suñama did not let go of the line, his boat capsized. He tied his line to the capsized boat and followed the line to the shark, diverted the shark, then brought the billfish back to his boat, which he righted and sailed home flying a woven mat from the masthead to indicate a successful catch. Sancho concluded that the Chamorro were "the most skilled fishermen ever to have been discovered" (Driver 1983:15).

The Chamorro culture was drastically impacted by Spanish colonisation in 1668 and the subsequent events. Guam was colonised when the first permanent mission in the Marianas was established. The superior of the mission was Father Diego Luis de Sanvitores, a Jesuit priest who arrived at Guam on June 15, 1668 (Carano and Sanchez 1964). Along with Father Sanvitores were four other Jesuit priests, a scholastic brother and lay assistants. In addition to the missionaries, there was a garrison force consisting of a captain, Don Juan de Santa Cruz, and thirty-two soldiers.

After an initial period of apparent success in converting the islanders to Roman Catholicism, the mission met with hostility. Open rebellion on the part of the Chamorro against the Spaniards broke out in 1670. Father Medina was killed on Saipan in 1670, and Father Sanvitores was killed 
on Guam in 1672. In his history of the years 1668-1681, García (1985) recorded how Spanish military commanders and governors burned Chamorro villages and canoes, pursued fleeing canoes, and rounded up fugitives who had fled from Guam to Rota. The Spanish-Chamorro Wars continued for 25 years until 1695 when the final battle took place on Aguijan, where the Chamorro people from Tinian had taken refuge but were finally overwhelmed by Governor José de Quiroga and his men. At the end of the Spanish-Chamorro Wars, the Spanish required the people of the Northern Marianas to move to Guam. By the middle of 1699, only Saipan and Rota in the Northern Marianas were still inhabited (Farrell 1991). Rota was never completely depopulated, but all of the islands north of Rota had been depopulated by about 1740 .

Pelagic fishing during the Prehistoric Period and the first couple hundred years of the Spanish Period depended on the flying proa, the large ocean-going sailing canoe. In Canoes of Oceania, Haddon and Hornell (1975) said, "More than those of any other island group, the sailing craft of the Mariana Islands, by reason of their swiftness and elegance, riveted the attention and aroused the admiration of every navigator who had the good fortune to see them."

The flying proa, which had first been described in the 1500s, was seen and described by William Dampier in 1686 (Dampier 1937), Captain Woodes Rogers in 1710 (Rogers 1928), and George Anson in 1742 (Anson 1748; Barratt 1988). Anson and some of his lieutenants captured a proa on their arrival at Tinian, later dismantled it, and then burned it before they left the island (Barratt 1988:11, 14, 69). Their descriptions and drawings of the proa are among the last in history (Figure 12 , below).

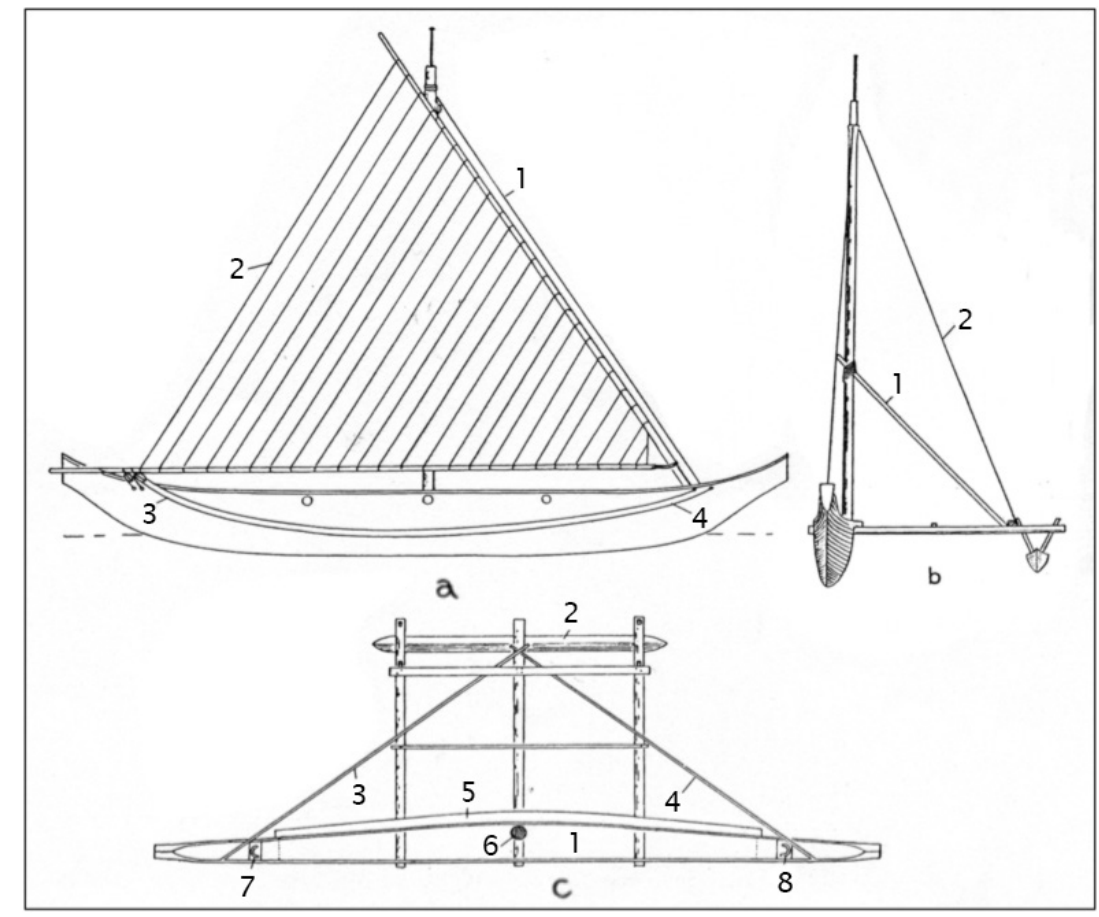

Figure 12." "Flying proa" of the Mariana Islands. a, view from leeward with sail set: 1, one of two stays supporting mast, the other hidden behind sail; 2, matting sail; 3, 4, running stays. b, head view, outrigger to windward: 1, mast shore; 2, shroud. c, plan: 1, proa; 2, "boat" at end of outrigger frame; 3, 4, braces from the ends to steady frame; 5 , thin plank placed to windward to prevent shipping of water, to serve as seat for native who bales, and sometimes as rest for goods transported; 6 , part of middle outrigger boom on which mast is fixed; 7,8 , horseshoe sockets, in one of which yard is lodged according to tack (after Anson 1748).

Source: Figure and caption from Haddon and Hornell (1975:414). 
Anson arrived at Tinian more than 40 years after the Chamorro had been moved to Guam, so he found no permanent population there. Instead he encountered a party of about two dozen men, islanders under the command of a Spanish sergeant, who had come from Guam to kill and cure beef for the garrison in Guam and for the Spanish galleon, which would stop on her way from Acapulco to Manila. The Anson expedition estimated the number of cattle on Tinian at 10,000, and there was an abundance of wild hogs and domestic poultry (Barratt 1988:46).

Haddon and Hornell noted that the last voyager to describe the flying proa of the Chamorro was Captain Crozet (1891), who spent nearly two months on Guam in 1772. However, they questioned his description because it "coincides so closely with that of Dampier that it is impossible to resist the conclusion that Crozet had Dampier's account before him as he wrote and that he based his own almost entirely upon it" (Haddon and Hornell 1975:417). As proof of their conclusion, they cited the fact that Crozet repeated Dampier's error in saying that the outrigger was on the lee side of the boat, rather than the windward side, as correctly reported by other writers.

It appears that Anson was the last European visitor to see the flying proa in use, and even then it was put to the unusual use of transporting meat from Tinian, rather than pelagic fishing. Pelagic fishing by the Chamorro apparently came to an end by about 1750 if not before. When Governor Henrique Olavide took office in 1749, he noted a lack of sea-going vessels. He had three 30foot vessels built in Guam, and he had eleven bancas (sea-going canoes) built for inter-island travel—six in Guam, four in Rota, and one in Tinian (Driver 2005:37). Governor José de Soroa, who took office in 1759, sent bancas to Tinian for meat (Driver 2005:38). During Governor José Arlegui's administration (1786-1794), several disasters highlighted the importance of the Refaluwasch or Carolinians and their ocean-going canoes (Driver 2005:54-57). By this time, inter-island travel was dependent on the Refaluwasch. The Refaluwasch bancas traveled from Guam to Rota for purposes of the government and church, and they traveled to Tinian to obtain meat and produce.

\section{(2) Early and mid twentieth century}

Just prior to the beginning of the $20^{\text {th }}$ century, Spain lost control of the Mariana Islands. Guam was ceded to the U.S. in 1898 as a result of the Spanish-American War, and in 1899 Germany purchased the Mariana Islands north of Guam (Figure 13). The histories of Guam and the Northern Mariana Islands continued to diverge as Japan occupied the Northern Marianas for 30 years, while Guam was occupied by the Japanese for less than three years during World War II. Both Guam and the Northern Marianas have been part of the U.S. since 1944, but their governments have never been reunited.

Georg Fritz, the District Officer of the German (Northern) Mariana Islands from 1899-1907 wrote in Die Chamorro, which was published in 1904, that fishing was the main source of food for the islanders, but it took place only inside the reef. He mentioned that the Carolinians sometimes went on the high seas to Aguijan to dive for trepang, which they sold to the Japanese. He also said the Carolinians took turtle, but if they caught pelagic fish, Fritz did not record that.

In 1914, soon after the beginning of World War I, Saipan was seized by Japan. During the 1920s and 30s, the Japanese operated a pole-and-line fishery out of Saipan for bonito (skipjack tuna) and tuna (probably yellowfin tuna), which was the first large-scale commercial fishery in the Marianas. Labour was imported from Japan and Okinawa, and the catch was shipped to Japan. According to statistics obtained from Japan (Higuchi 2007), skipjack catches in Saipan District (Saipan, Tinian, and Rota) peaked at nearly 3700 metric tons or more than 8 million pounds in 1937 (Table 5). Yellowfin catches peaked at 151 metric tons or almost 333,000 pounds in 1936. 
Table 5. Bonito and tuna from Saipan District, 1922 through 1941.

\begin{tabular}{|c|c|c|c|c|}
\hline YEAR & BONITO* (mt) & BONITO (1000 lbs) & TUNA ${ }^{* *}(\mathrm{mt})$ & TUNA (1000 lbs) \\
\hline 1922 & 2.4 & 5.2 & 1.3 & 2.9 \\
\hline 1923 & 2.8 & 6.2 & 1.3 & 2.8 \\
\hline 1924 & 9.1 & 20.1 & 1.5 & 3.4 \\
\hline 1925 & 14.8 & 32.6 & 1.4 & 3.1 \\
\hline 1926 & 44.8 & 98.9 & 2.3 & 5.1 \\
\hline 1927 & 28.1 & 62.0 & 2.9 & 6.4 \\
\hline 1928 & 26.5 & 58.4 & 1.3 & 2.8 \\
\hline 1929 & 24.7 & 54.4 & 0.6 & 1.2 \\
\hline 1930 & 258.0 & 568.8 & 4.5 & 10.0 \\
\hline 1931 & 564.3 & $1,244.0$ & 16.7 & 36.9 \\
\hline 1932 & $1,309.7$ & $2,887.4$ & 48.2 & 106.4 \\
\hline 1933 & $1,762.3$ & $3,885.2$ & 9.6 & 21.1 \\
\hline 1934 & $2,516.0$ & $5,546.8$ & 27.3 & 60.2 \\
\hline 1935 & $1,786.0$ & $3,937.4$ & 42.9 & 94.6 \\
\hline 1936 & $1,696.0$ & $3,739.1$ & 151.0 & 332.9 \\
\hline 1937 & $3,697.3$ & $8,151.1$ & 88.9 & 195.9 \\
\hline 1938 & $2,592.0$ & $5,714.4$ & 33.9 & 74.8 \\
\hline 1939 & $1,297.4$ & $2,860.2$ & not available & not available \\
\hline 1940 & $3,379.0$ & $7,449.5$ & 84.5 & 186.3 \\
\hline 1941 & $1,297.4$ & $2,860.2$ & 33.7 & 74.2 \\
\hline
\end{tabular}

* skipjack tuna.

** probably yellowfin tuna.

Source: This table is adapted from Higuchi (2007).

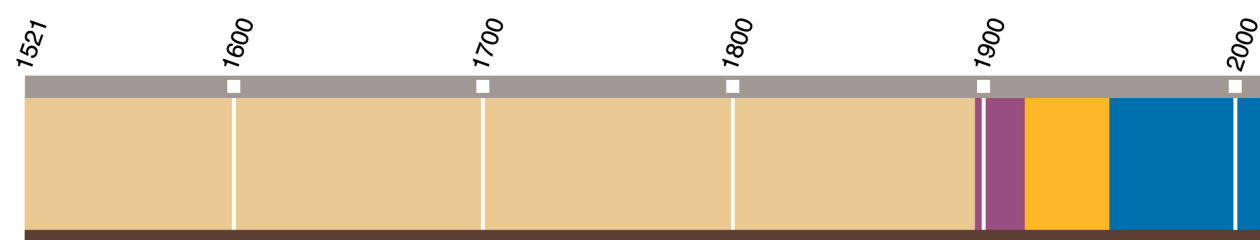

NORTHERN MARIANAS

HISTORIC PERIOD

\begin{tabular}{l|l|l|l}
$\begin{array}{l}\text { Spanish Period } \\
(1521-1899)\end{array}$ & $\begin{array}{l}\text { German Period } \\
(1899-1914)\end{array}$ & $\begin{array}{l}\text { Japanese Period } \\
(1914-1944)\end{array}$
\end{tabular}$\quad \begin{aligned} & \text { American Period } \\
& (1944-p r e s e n t)\end{aligned}$

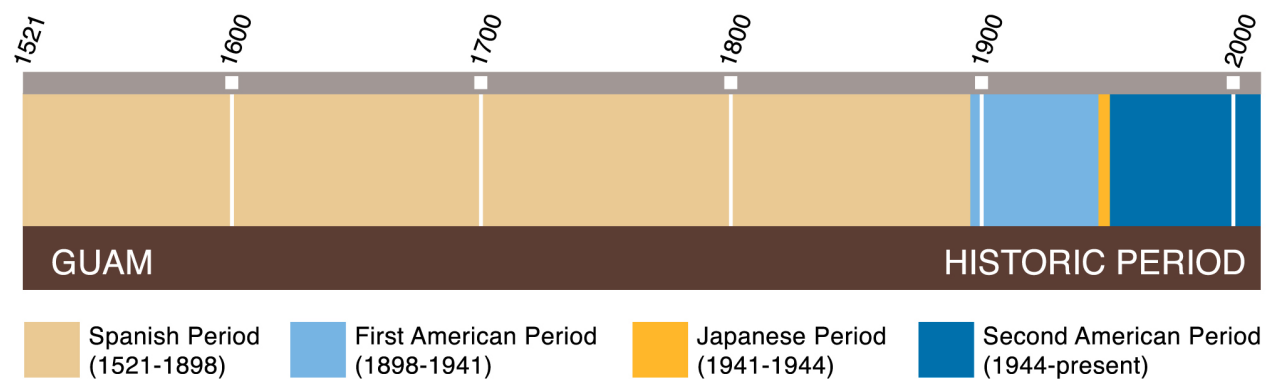

Figure 13. Timelines of the Historic Period in Guam and the CNMI.

Source: Figure by Robert Amesbury. 
The American capture of Saipan in July 1944 put an end to the Japanese fishery there. All of the boats were either sunk in the harbour or beached and burned. Soon after the end of hostilities, the sunken hulls were raised from the lagoon and reconstructed by Japanese and Okinawan carpenters prior to the repatriation of Japanese nationals in 1946. Four boats were restored to use in Saipan and Tinian, and the fish caught were used to feed the interned civilians.

From 1946 through 1950, three of the four boats were put to use by a cooperative of Carolinian fishermen, known as the Saipan Fishing Company. Capital for the Saipan Fishing Company came from a small group of Carolinian men who were employed as policemen. One of those policemen was the father of Lino Olopai (Figure 14). The father of Rafael Rangamar (Figure 14) was the captain of one of the boats. Olopai and Rangamar went out on the boats as children and recalled the excitement of pole-and-line fishing in an interview in Saipan in 2005 (Amesbury and Hunter-Anderson 2008).

Post-war production of the commercial fishing industry was greatly reduced from the pre-war Japanese production (Bowers 2001). More than 3500 metric tons (more than 8 million pounds) of bonito were harvested in 1937, compared with fewer than 100 metric tons (fewer than 200,000 pounds) in 1948 (Table 6). Spoehr (2000:129) reported that by 1950 the Saipan Fishing Company was on the verge of bankruptcy. Fewer than 11 metric tons of fish had been caught in the first nine months of 1950, and about two metric tons had been lost to spoilage. When the Saipan Fishing Company ended in 1950 or soon after, the men fished for their own families.

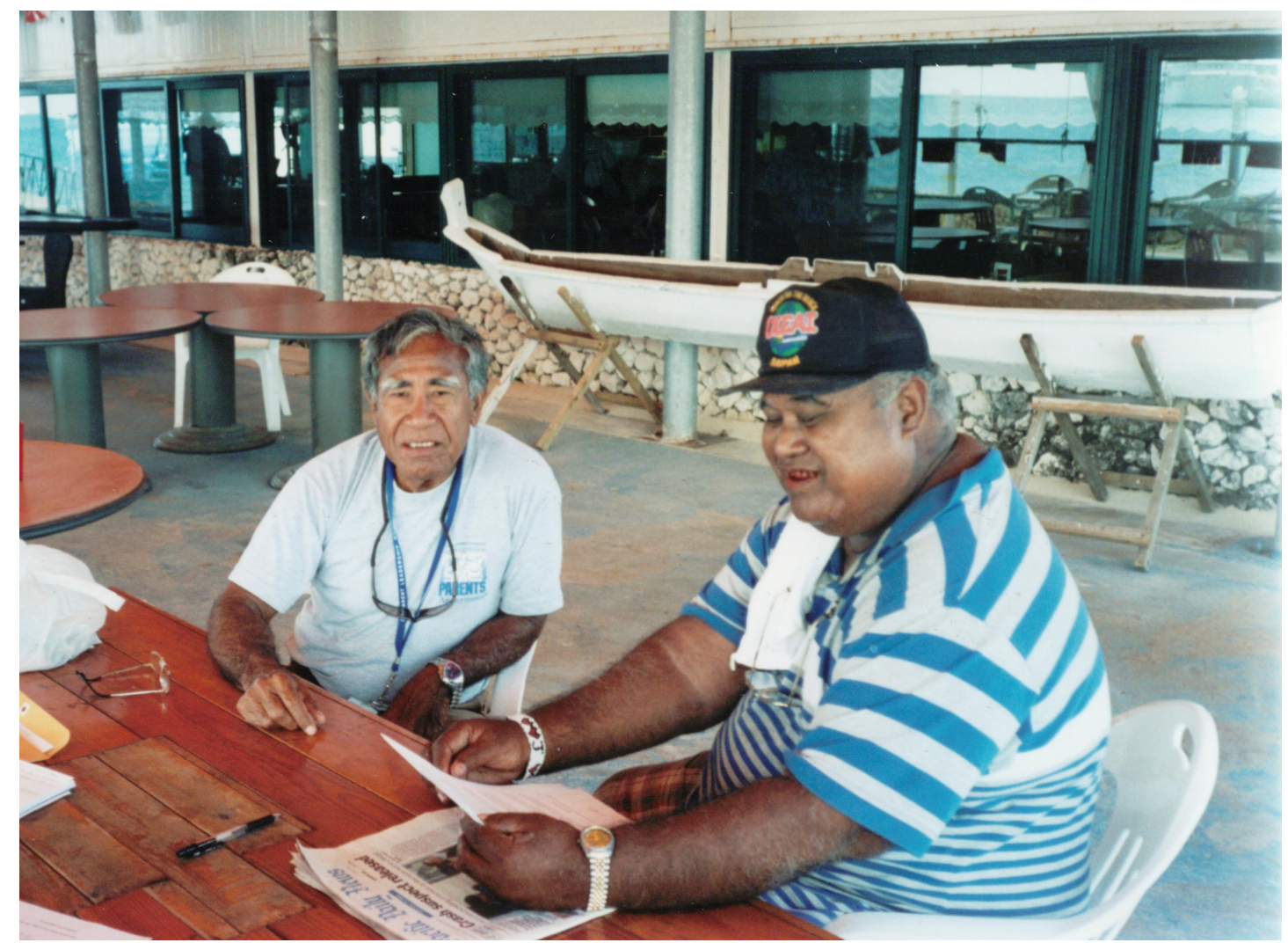

Figure 14. Lino Olopai and Rafael Rangamar at the Seaman's Restaurant, Saipan, February 2005.

Source: Photo by Judith Amesbury. 
Table 6. Pre-war and post-war production of the commercial fishing industry, Saipan District.

\begin{tabular}{lrrrr}
\hline MARINE PRODUCTS & $\mathbf{1 9 3 7}$ (mt) & $\mathbf{1 9 3 7}$ (1000 lbs) & 1948 (mt) & $\mathbf{1 9 4 8}$ (1000 lbs) \\
\hline Fish & & & & \\
Bonito & $3,697.3$ & $8,151.1$ & & \\
Tuna & 88.9 & 195.9 & & \\
Mackerel & 14.5 & 32.0 & & \\
Mullet & 0.2 & 0.4 & & \\
Shark & 5.8 & 12.8 & & \\
Other fish & 153.3 & 338.0 & & \\
Total Fish & $\mathbf{3 , 9 6 0 . 0}$ & $\mathbf{8 , 7 3 0 . 2}$ & $\mathbf{8 1 . 1}$ & $\mathbf{1 7 8 . 9}$ \\
Other Marine Products & & & & \\
Trepang & 22.1 & 48.7 & 0.00 & 0.00 \\
Trochus & & & 0.00 & 0.00 \\
Turtle & & & 0.03 & 0.06 \\
Lobster & & & 0.40 & 0.88 \\
Total Other Marine Products & $\mathbf{2 2 . 1}$ & $\mathbf{4 8 . 7}$ & $\mathbf{0 . 4 3}$ & $\mathbf{0 . 9 4}$ \\
Grand Total & $\mathbf{3 , 9 8 2 . 1}$ & $\mathbf{8 , 7 7 8 . 9}$ & $\mathbf{8 1 . 5 3}$ & $\mathbf{1 7 9 . 8 4}$ \\
\hline
\end{tabular}

Source: This table is adapted from Bowers (2001).

Spoehr (2000:129-130) cited four factors in the demise of the Saipan Fishing Company. The fishermen were more familiar with reef and lagoon fishing than deep-sea fishing for bonito and tuna, and maintenance of the fishing boats was a problem. Management of the commercial venture was lacking, and there were difficulties in transporting the fish to market in Guam and in marketing the fish there.

Meanwhile in pre-war Guam, the U.S. Naval Government decided to teach Chamorro men to fish beyond the reef. From 1933 to 1937, twelve men at a time were trained for a period of three months (U.S. Naval Government of Guam 1934-1937). For safety's sake, the instruction took place within view of a fishing lookout at Orote Point, and each boat carried trained homing pigeons to carry messages in case of emergency. Offshore fishing did not develop at that time due to a lack of boats.

After World War II, cash was scarce, but as the economy improved in the 1950s and 60s, the local people in the Marianas began to buy boats and outboard motors and troll for pelagic species. Most of the boats were imported from the U.S., but some were built locally. The year 1956 is the first year in which tuna or trolling catch is listed separately in the fishery statistics of the post-war governors' annual reports for Guam (Governors of Guam 1951-1970).

In an interview with Amesbury and Hunter-Anderson (2008), Lino Lizama of Tinian told an unusual story about how his father acquired a boat. In the mid-1960s, his father found a large quantity of brass from machine gun shells left by the U.S. military at a place on the northwest coast of Tinian called Dumpcoke, where the military dumped Coke bottles among other things. Lizama's father tied a weapons carrier to a big tree and used the winch on the weapons carrier to raise the drum cans of brass. He sold the brass and used the money to purchase an 18-foot wooden boat built on Saipan by his cousin's husband, Pobio Cabrera. He also bought a 40-horsepower Evinrude engine. The name of the boat was Bithen de Carmen. Lizama said that in the mid1960s there were only three or four boats on Tinian. The late Antonio Mesngon Sr., a fisherman on Rota, said that in the 1960s there were only about four boats on Rota also, although there were more on Saipan and Guam. 


\section{(3) Late twentieth century to the present}

Five species make up approximately ninety-five percent of the trolling catch in the Marianas: mahimahi (Coryphaena hippurus), skipjack tuna (Katsuwonus pelamis), wahoo (Acanthocybium solandri), yellowfin tuna (Thunnus albacares), and blue marlin (Makaira nigricans). An economic boom, which began in the late 1980s and continued through most of the 1990s, led to an increase in number of boats. Now hundreds of thousands of pounds of pelagic fish are landed by small boat fishermen each year.

The Guam Division of Aquatic and Wildlife Resources (DAWR, formerly Division of Fish and Wildlife) began to collect data on fisheries beginning in the 1960s. Surveys done the way they are done now began in 1979 for boat-based fisheries and in 1982 for coastal fisheries. In 1981 the National Marine Fisheries Service's (NMFS) Southwest Fisheries Science Center (SWFSC) started the Western Pacific Fishery Information Network (WPacFIN) to work cooperatively with the U.S. Pacific islands fisheries agencies to collect and disseminate fisheries statistics. These statistics are available through the WPacFIN website and the administrative reports produced by the Honolulu Laboratory, SWFSC.

Beginning in 1987, the Pelagics Plan Team and staff of the Western Pacific Regional Fishery Management Council (WPRFMC) have produced reports to the Council on the pelagic fisheries of the Western Pacific region based on the statistics produced by the island agencies and WPacFIN. The WPRFMC reports use the Guam data from 1982 on. Table 7 shows the estimated total landings in Guam of the five most abundant pelagic species from 1982 through 2009. These include non-charter and charter landings.

The WPRFMC reports provide information on effort, including estimated number of trolling boats, estimated number of trolling trips, estimated number of trolling hours, estimated trip length, and catch per unit effort (CPUE) in terms of pounds per hour. The WPRFMC reports also provide economic data including average price per pound of pelagic species, annual consumer price indexes (CPI) and CPI adjustment factors, inflation-adjusted commercial revenues, annual estimated inflation-adjusted average prices, and annual estimated inflation-adjusted revenue per trolling trip.

Since the early 1980s, the CNMI Division of Fish and Wildlife (DFW) has collected data on fishing. DFW distributes and collects invoice books from participating fish vendors on Saipan. In this way approximately 90 percent of the commercial landings on Saipan are recorded. WPacFIN compiles and expands the data to represent the entire CNMI. The data from 1983 on are considered the most accurate. Table 8 shows commercial landings of pelagic fishes on Saipan from 1983 through 2009. 
Table 7. Estimated total landings of pelagic fishes by metric tons \& 1000 pounds in Guam.

\begin{tabular}{|c|c|c|c|c|c|c|c|c|c|c|}
\hline \multirow[t]{2}{*}{ YEAR } & \multicolumn{2}{|c|}{ МАНІМАНІ } & \multicolumn{2}{|c|}{ SKIPJACK } & \multicolumn{2}{|c|}{ WАНОO } & \multicolumn{2}{|c|}{ YELLOWFIN } & \multicolumn{2}{|c|}{ BLUE MARLIN } \\
\hline & $\mathrm{mt}$ & $1000 \mathrm{lbs}$ & $\mathrm{mt}$ & 1000 lbs & $\mathrm{mt}$ & $1000 \mathrm{lbs}$ & $\mathrm{mt}$ & 1000 lbs & $\mathrm{mt}$ & $1000 \mathrm{lbs}$ \\
\hline 1982 & 50.8 & 112.0 & 57.5 & 126.7 & 25.4 & 55.9 & 51.1 & 112.7 & 9.9 & 21.8 \\
\hline 1983 & 70.9 & 156.3 & 44.4 & 97.8 & 39.2 & 86.5 & 29.9 & 66.0 & 13.8 & 30.4 \\
\hline 1984 & 11.9 & 26.2 & 99.0 & 218.3 & 24.4 & 53.8 & 30.8 & 68.0 & 22.4 & 49.4 \\
\hline 1985 & 32.8 & 72.4 & 50.0 & 110.3 & 56.1 & 123.7 & 43.2 & 95.3 & 25.4 & 55.9 \\
\hline 1986 & 45.9 & 101.1 & 35.5 & 78.3 & 31.9 & 70.3 & 25.4 & 56.0 & 25.9 & 57.1 \\
\hline 1987 & 36.1 & 79.5 & 28.0 & 61.8 & 39.2 & 86.5 & 18.8 & 41.4 & 22.4 & 49.4 \\
\hline 1988 & 153.2 & 337.8 & 97.2 & 214.3 & 44.8 & 98.7 & 39.1 & 86.3 & 27.9 & 61.4 \\
\hline 1989 & 43.6 & 96.0 & 58.2 & 128.2 & 57.8 & 127.3 & 18.4 & 40.5 & 38.8 & 85.5 \\
\hline 1990 & 63.8 & 140.6 & 67.8 & 149.5 & 38.6 & 85.1 & 32.8 & 72.4 & 43.0 & 94.8 \\
\hline 1991 & 188.7 & 415.9 & 53.8 & 118.7 & 25.4 & 55.9 & 20.0 & 44.0 & 39.9 & 87.9 \\
\hline 1992 & 39.9 & 87.9 & 56.0 & 123.4 & 37.4 & 82.4 & 60.4 & 133.2 & 38.3 & 84.5 \\
\hline 1993 & 106.6 & 235.0 & 49.7 & 109.6 & 28.4 & 62.6 & 22.8 & 50.4 & 26.3 & 58.0 \\
\hline 1994 & 62.6 & 138.0 & 85.6 & 188.8 & 22.9 & 50.5 & 32.3 & 71.2 & 34.8 & 76.6 \\
\hline 1995 & 148.3 & 327.0 & 81.2 & 179.0 & 35.1 & 77.4 & 42.4 & 93.5 & 34.7 & 76.6 \\
\hline 1996 & 148.9 & 328.3 & 108.2 & 238.6 & 66.5 & 146.5 & 48.6 & 107.0 & 29.0 & 63.9 \\
\hline 1997 & 120.3 & 265.2 & 99.4 & 219.2 & 29.5 & 65.0 & 40.9 & 90.2 & 41.2 & 90.8 \\
\hline 1998 & 120.0 & 264.5 & 91.5 & 201.7 & 71.8 & 158.2 & 62.3 & 137.4 & 20.0 & 44.1 \\
\hline 1999 & 73.5 & 161.9 & 56.0 & 123.5 & 34.6 & 76.3 & 58.1 & 128.0 & 36.5 & 80.5 \\
\hline 2000 & 38.8 & 85.6 & 121.4 & 267.7 & 31.9 & 70.4 & 34.8 & 76.7 & 39.2 & 86.4 \\
\hline 2001 & 83.1 & 183.3 & 150.5 & 331.8 & 54.3 & 119.8 & 26.3 & 57.9 & 15.1 & 33.3 \\
\hline 2002 & 78.5 & 173.1 & 80.0 & 176.4 & 33.0 & 72.6 & 20.5 & 45.1 & 24.4 & 53.8 \\
\hline 2003 & 38.4 & 84.7 & 84.2 & 185.6 & 29.2 & 64.3 & 32.5 & 71.6 & 30.9 & 68.2 \\
\hline 2004 & 88.9 & 195.9 & 76.6 & 168.8 & 54.6 & 120.3 & 47.6 & 105.0 & 17.6 & 38.8 \\
\hline 2005 & 48.0 & 105.7 & 45.1 & 99.4 & 19.9 & 43.9 & 11.3 & 24.9 & 4.2 & 9.3 \\
\hline 2006 & 73.7 & 162.5 & 66.5 & 146.7 & 48.0 & 105.9 & 12.7 & 28.0 & 13.3 & 29.2 \\
\hline 2007 & 117.9 & 259.8 & 71.6 & 157.9 & 20.2 & 44.5 & 21.8 & 48.1 & 8.6 & 19.0 \\
\hline 2008 & 50.7 & 111.8 & 133.9 & 295.3 & 44.6 & 98.3 & 9.0 & 19.9 & 4.4 & 9.7 \\
\hline 2009 & 66.5 & 146.6 & 150.2 & 331.1 & 59.3 & 130.7 & 22.8 & 50.3 & 14.8 & 32.6 \\
\hline 28 Year Average & 78.6 & 173.4 & 78.5 & 173.2 & 39.4 & 86.9 & 32.7 & 72.2 & 25.1 & 55.3 \\
\hline Percent of Five Species & & 30.9 & & 30.9 & & 15.5 & & 12.9 & & 9.9 \\
\hline
\end{tabular}

Source: This table is adapted from WPRFMC (2011). 
Table 8. Total commercial landings of pelagic fishes by metric tons \& 1000 Pounds in the CNMI.

\begin{tabular}{|c|c|c|c|c|c|c|c|c|c|c|}
\hline \multirow[t]{2}{*}{ YEAR } & \multicolumn{2}{|c|}{ SKIPJACK } & \multicolumn{2}{|c|}{ YELLOWFIN } & \multicolumn{2}{|c|}{ МАНІМАНІ } & \multicolumn{2}{|c|}{ WAHOO } & \multicolumn{2}{|c|}{ BLUE MARLIN } \\
\hline & $\mathrm{mt}$ & $\begin{array}{r}1000 \\
\text { Ibs }\end{array}$ & $\mathrm{mt}$ & $\begin{array}{r}1000 \\
\text { lbs }\end{array}$ & $\mathrm{mt}$ & $\begin{array}{r}1000 \\
\text { lbs }\end{array}$ & mt & $\begin{array}{r}1000 \\
\text { lbs }\end{array}$ & mt & $\begin{array}{r}1000 \\
\text { lbs }\end{array}$ \\
\hline 1983 & 83.2 & 183.4 & 9,7 & 21.3 & 6.3 & 13.9 & 4.0 & 8.8 & 1.7 & 3.8 \\
\hline 1984 & 131.9 & 290.8 & 8.9 & 19.6 & 3.5 & 7.6 & 6.4 & 14.1 & 0.7 & 1.5 \\
\hline 1985 & 80.4 & 177.3 & 5.7 & 12.5 & 5.9 & 13.0 & 8.3 & 18.3 & 0.8 & 1.9 \\
\hline 1986 & 115.4 & 254.4 & 7.7 & 16.9 & 8.1 & 17.8 & 4.1 & 9.1 & 1.2 & 2.7 \\
\hline 1987 & 73.3 & 161.5 & 4.7 & 10.5 & 4.3 & 9.5 & 6.1 & 13.4 & 1.1 & 2.5 \\
\hline 1988 & 120.9 & 266.5 & 7.0 & 15.4 & 14.0 & 30.8 & 5.3 & 11.7 & 0.6 & 1.3 \\
\hline 1989 & 116.9 & 257.7 & 4.6 & 10.1 & 3.3 & 7.3 & 0.7 & 1.6 & 2.6 & 5.7 \\
\hline 1990 & 67.1 & 148.0 & 4.7 & 10.5 & 4.7 & 10.4 & 1.6 & 3.5 & 0.9 & 2.0 \\
\hline 1991 & 52.5 & 115.8 & 5.9 & 13.0 & 15.3 & 33.8 & 0.7 & 1.5 & 0.7 & 1.6 \\
\hline 1992 & 37.3 & 82.3 & 11.7 & 25.7 & 11.9 & 26.3 & 7.8 & 17.2 & 3.0 & 6.6 \\
\hline 1993 & 44.1 & 97.3 & 6.8 & 14.9 & 17.0 & 37.5 & 1.3 & 2.8 & 1.7 & 3.7 \\
\hline 1994 & 41.8 & 92.2 & 6.1 & 13.4 & 6.8 & 15.1 & 1.8 & 3.9 & 1.2 & 2.6 \\
\hline 1995 & 59.6 & 131.4 & 9.5 & 20.9 & 10.6 & 23.3 & 2.6 & 5.7 & 3.0 & 6.6 \\
\hline 1996 & 74.9 & 165.0 & 17.3 & 38.0 & 16.2 & 35.7 & 4.9 & 10.8 & 3.9 & 8.6 \\
\hline 1997 & 60.5 & 133.4 & 9.7 & 21.4 & 14.2 & 31.3 & 3.4 & 7.6 & 3.2 & 7.1 \\
\hline 1998 & 75.8 & 167.1 & 6.6 & 14.6 & 11.5 & 25.4 & 2.9 & 6.3 & 1.9 & 4.2 \\
\hline 1999 & 48.2 & 106.3 & 11.1 & 24.4 & 5.8 & 12.9 & 3.7 & 8.1 & 1.6 & 3.5 \\
\hline 2000 & 63.7 & 140.4 & 8.0 & 17.7 & 3.3 & 7.3 & 1.9 & 4.1 & 1.6 & 3.6 \\
\hline 2001 & 60.7 & 133.8 & 6.6 & 14.5 & 6.5 & 14.2 & 2.1 & 4.6 & 0.9 & 1.9 \\
\hline 2002 & 81.6 & 180.0 & 13.6 & 30.0 & 8.2 & 18.0 & 3.7 & 8.2 & 0.6 & 1.3 \\
\hline 2003 & 77.8 & 171.6 & 11.8 & 26.0 & 3.3 & 7.4 & 3.6 & 8.0 & 0.5 & 1.1 \\
\hline 2004 & 67.3 & 148.3 & 12.5 & 27.5 & 16.2 & 35.8 & 3.1 & 6.9 & 0.9 & 2.0 \\
\hline 2005 & 118.2 & 260.6 & 23.6 & 52.0 & 12.2 & 26.9 & 1.5 & 3.3 & 0.7 & 1.6 \\
\hline 2006 & 120.5 & 265.8 & 19.0 & 42.0 & 7.8 & 17.2 & 1.4 & 3.1 & 0.6 & 1.4 \\
\hline 2007 & 108.4 & 239.0 & 15.8 & 34.9 & 12.0 & 26.4 & 1.1 & 2.5 & 0.03 & 0.1 \\
\hline 2008 & 77.1 & 170.1 & 8.5 & 18.7 & 6.0 & 13.2 & 0.8 & 1.7 & 0.9 & 2.0 \\
\hline 2009 & 58.6 & 129.2 & 11.4 & 25.1 & 8.9 & 19.6 & 1.5 & 3.4 & 0.02 & 0.0 \\
\hline 27 Year Average & 78.4 & 172.9 & 9.9 & 21.9 & 9.0 & 19.9 & 3.2 & 7.0 & 1.4 & 3.0 \\
\hline Percent of Five Species & & 76.9 & & 9.7 & & 8.9 & & 3.1 & & 1.3 \\
\hline
\end{tabular}

Source: This table is adapted from WPRFMC (2011).

The composition of the CNMI trolling catch is very different from that of the Guam trolling catch. In the CNMI, the average annual commercial trolling catch of skipjack exceeds 170,000 pounds, but yellowfin, mahimahi, wahoo, and marlin average less than 22,000 pounds each. On Guam, the average annual total trolling catches of both mahimahi and skipjack exceed 170,000 pounds each. The average annual trolling catches of wahoo, yellowfin, and marlin range from 87,000 to 55,000 pounds each. 
Figure 15 compares the 27-year average commercial landings in the CNMI (from Table 7) with the 28-year average total landings in Guam (from Table 8). The Saipan catch is more than 75 percent skipjack, while the Guam catch is more evenly divided between the five most abundant species. It is possible that the preference for skipjack in Saipan is a result of Saipan's history with the pre-war Japanese and post-war Carolinian pole-and-line fishery.

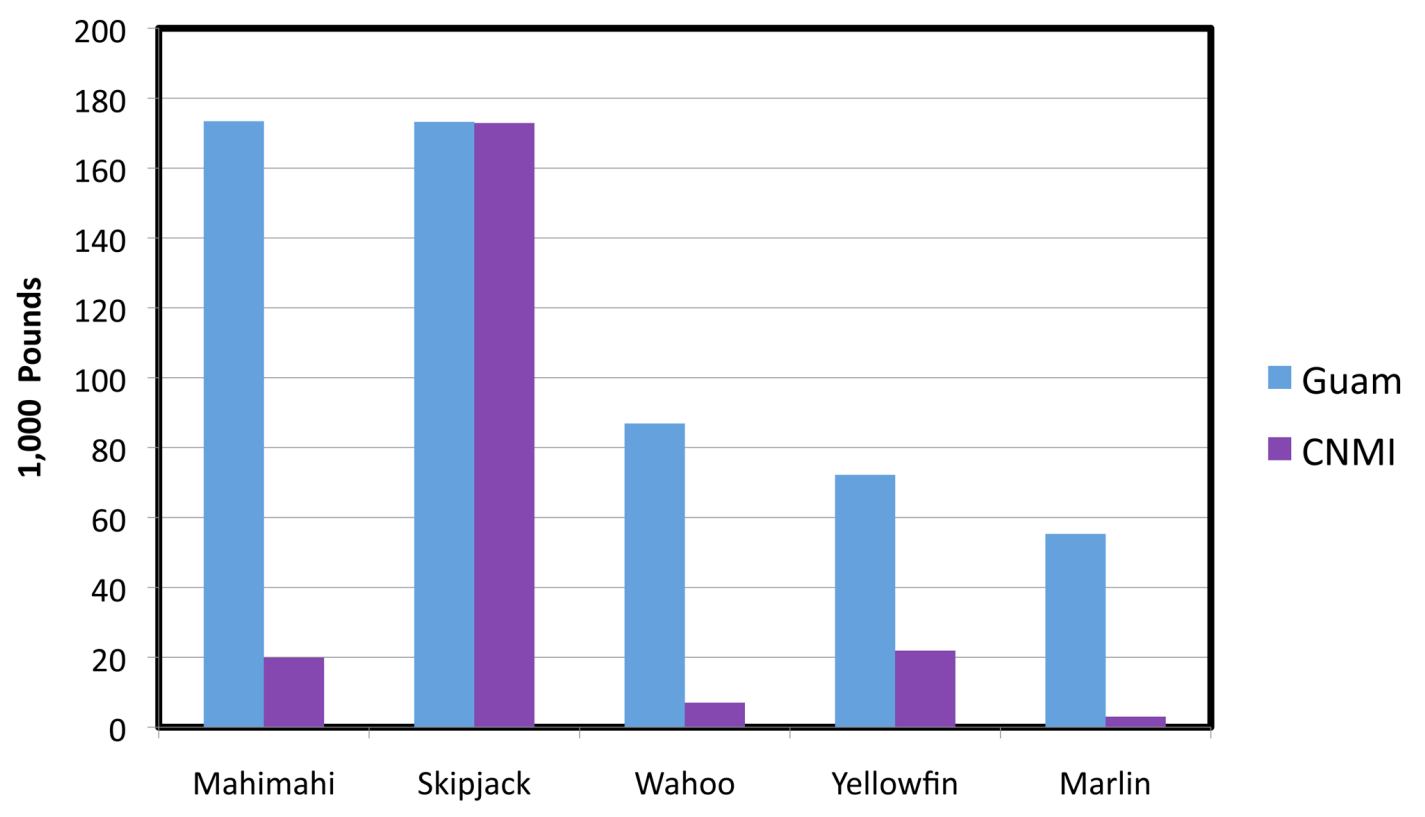

Figure 15. Composition of the trolling catch in Guam and Saipan, based on average annual catches.

Source: Figure by Judith Amesbury.

\section{Summary}

The first people to arrive in the Mariana Archipelago at least 3,500 years ago were skilled fishermen. No doubt their ability to reach the Marianas over a long distance of open ocean was accompanied by the ability to fish for open-ocean species. Analysis of fish bones from archaeological sites shows that the Chamorro fished for pelagic species, especially mahimahi and marlin, throughout the long Prehistoric Period (at least $1500 \mathrm{BC}$ to AD 1521). A comparison of ten sites with pelagic species and MNI analysis indicates that approximately sixteen percent of the fishes caught were pelagic species. It is noted that archaeological sites in southern Taiwan and the northern Philippines also have yielded bones of mahimahi and marlin from deposits which date to approximately the same time period as the Pre-Latte Phase in the Marianas.

Pelagic fishing continued into the Spanish Period with the addition of iron for fishhooks. The writers of the early Spanish Period described fishing for flying fish, mahimahi, and billfish. By all accounts the Chamorro were exceptionally skilled sailors and fishermen. However, when hostilities broke out soon after Spanish colonisation in 1668, the Chamorro people and culture were drastically affected. As a result of the 25-year long Spanish-Chamorro Wars and the Spanish policy of requiring nearly everyone in the Marianas to move to Guam, the flying proa was no longer built by about 1750 , and the Chamorro people did not participate in pelagic fishing for the next 200 years. Refaluwasch people from the Caroline Islands moved into the Marianas and took over inter-island travel during the second half of the 1700s and the 1800s. Both Chamorro and Carolinian people engaged in reef fishing. 
The next major development in pelagic fishing was the pole-and-line fishery operated by the Japanese in Saipan in the 1920s and 30s, which was the first commercial fishery in the Marianas. The labour was mostly Japanese and Okinawan, and the fish were exported to Japan. Extraordinarily large amounts of skipjack were caught. The Japanese fishery ended with the American takeover of Saipan in 1944. For a few years after the war, a cooperative of Carolinian fishermen tried to resume the pole-and-line fishery, but they did so with less success than the Japanese had. Meanwhile in pre-war Guam, the U.S. Navy decided to teach Chamorro men how to fish for pelagic species. A lack of boats prevented that idea from getting off the ground.

Boats became available in the 1950s and 60s as the economy improved after the war. Pelagic fishing had begun by 1956 according to the post-war Guam governors' reports. By the mid-1960s there were only a few boats on Tinian and Rota, but more on Guam and Saipan. Good fishery data from the 1980s on show that the small boat fishermen of the Marianas now land hundreds of thousands of pounds of pelagic fish annually. Five species (mahimahi, skipjack, wahoo, yellowfin, and marlin) make up about ninety-five percent of the catch. The Chamorro fishermen have reclaimed their heritage as great pelagic fishermen.

For additional fishery data from each of the time periods, see Amesbury and Hunter-Anderson (2008). The report is available on the website of the Pelagic Fisheries Research Program at http:// www.soest.hawaii.edu/pfrp/ under Other Publications.

\section{Acknowledgments}

This project was partly funded by Cooperative Agreement NA17RJ1230 between the Joint Institute for Marine and Atmospheric Research (JIMAR) and the National Oceanic and Atmospheric Administration (NOAA). The views expressed herein are those of the author and do not necessarily reflect the views of NOAA or any of its subdivisions. The author thanks Janet Davidson and Osamu Kataoka for their helpful reviews of this paper.

\section{References}

Amesbury, J.R. and R.L. Hunter-Anderson. 2008. An Analysis of Archaeological and Historical Data on Fisheries for Pelagic Species in Guam and the Northern Mariana Islands. Report prepared for Pelagic Fisheries Research Program, University of Hawai'i at Mānoa. Guam: Micronesian Archaeological Research Services. Available on the website of the Pelagic Fisheries Research Program at http://www. soest.hawaii.edu/pfrp/ under Other Publications.

Anson, Baron G. 1748. A Voyage Round the World (1740-1744). Compiled by Richard Walter. London: Martin Hopkinson Ltd.

Barratt, G. 1988. H.M.S. Centurion at Tinian, 1742: The Ethnographic and Historic Records. Saipan: CNMI Division of Historic Preservation. Micronesian Archaeological Survey Report No. 26.

Bowers, N.M. 2001. (First published 1950). Problems of Resettlement on Saipan, Tinian and Rota, Mariana Islands. Saipan: CNMI Division of Historic Preservation. Occasional Historical Papers Series No. 7.

Campos, F.Z. 2009. The Ichthyoarchaeology of Batanes Islands, Northern Philippines. Unpublished master's thesis, Archaeology, University of the Philippines.

Carano, P. and P.C. Sanchez. 1964. A Complete History of Guam. Rutland: Charles E. Tuttle Company.

Craib, J.L. 1986. Casas de los Antiguos: Social Differentiation in Protohistoric Chamorro Society, Mariana Islands. Unpublished doctoral dissertation, University of Sydney. 
Craib, J.L. 1990. Archaeological Investigations at Mochong, Rota, Mariana Islands. Report submitted to the Office of Historic Preservation, Commonwealth of the Northern Mariana Islands. Melbourne: Department of Archaeology, La Trobe University.

Crozet, Captain. 1891. Crozet's Voyage to Tasmania, New Zealand, the Ladrone Islands, and the Philippines in the Years 1771-1772. Translated by H. Ling Roth. London: Truslove and Shirley.

Dampier, W. 1937. A New Voyage Round the World. London: Adam and Charles Black.

Donaldson, T.J., R.F. Myers, J.T. Moyer, and P.J. Schupp. 1994. Zoogeography of fishes of the Mariana, Ogasawara and Izu Islands: A preliminary assessment. In A. Asakura and T. Furuki (eds), Biological Expedition to the Northern Mariana Islands, Micronesia, pp. 303-332. Chiba: Natural History Museum and Institute. Natural History Research Special Issue No. 1.

Driver, M.G. 1983. Fray Juan Pobre de Zamora and his account of the Mariana Islands. Journal of Pacific History 18(3):198-216.

Driver, M.G. 2005. The Spanish Governors of the Mariana Islands. Guam: Micronesian Area Research Center, University of Guam. MARC Educational Series No. 27.

Farrell, D.A. 1991. History of the Northern Mariana Islands. Saipan: CNMI Public School System.

García, F. 1985. The Life and Martyrdom of the Venerable Father Diego Luis de Sanvitores. Translated by Margaret Higgens. Guam: Nieves M. Flores Memorial Library.

Governors of Guam 1951-1970. Annual Reports. On file at Micronesian Area Research Center, University of Guam.

Graves, M.W. 1986. Organization and differentiation within late prehistoric ranked social units, Mariana Islands, Western Pacific. Journal of Field Archaeology 13(2):139-154.

Haddon, A.C. and J. Hornell. 1975. Canoes of Oceania. Honolulu: Bishop Museum Press. Bernice P. Bishop Museum Special Publications 27, 28, and 29.

Higuchi, W. 2007. Pre-war Japanese fisheries in Micronesia: Focusing on bonito and tuna fishing in the Northern Mariana Islands. Immigration Studies 3:49-68. Okinawa: Center for Migration Studies, University of the Ryukyus.

Hsu, Y.C. 1982. Yami Fishing Practices: Migratory Fish. Taipei: Southern Materials Centre Inc.

Hunter-Anderson, R.L. and D.R. Moore 2002. Phase I and Phase II Archaeological Survey at Waterfront Annex and Ordnance Annex, Territory of Guam. Prepared under Contract No. N26742-97-D-3511, Task Order 12, Task 1 between International Archaeological Research Institute, Inc. and the Department of the Navy, Pacific Division, Naval Facilities Engineering Command, Pearl Harbor. Guam: Micronesian Archaeological Research Services.

Kano, T. and K. Segawa. 1956. An Illustrated Ethnography of Formosan Aborigines, Volume 1: The Yami. Tokyo: Maruzen Co. Ltd.

Leach, F. and J. Davidson. 2000. Fishing, a neglected aspect of Oceanic economy. In A. Anderson and T. Murray (eds), Australian Archaeologist: Collected Papers in Honour of Jim Allen, pp. 412-426. Canberra: Coombs Academic Publishing and The Australian National University.

Leach, B.F. and J.M. Davidson. 2006a. Analysis of Faunal Material from an Archaeological Site Complex at Mangilao, Guam. Technical Report 38. Wellington: Museum of New Zealand Te Papa Tongarewa.

Leach, B.F. and J.M. Davidson. 2006b. Analysis of Faunal Material from an Archaeological Site at Ylig, Guam. Technical Report 39. Wellington: Museum of New Zealand Te Papa Tongarewa. 
Leach, B.F., M. Fleming, J.M. Davidson, G.K. Ward, and J.L. Craib. 1990. Appendix C, Prehistoric Fishing at Mochong, Rota, Mariana Islands. In J.L. Craib (ed), Archaeological Investigations at Mochong, Rota, Mariana Islands, pp. C-1 to C-34. Submitted to the Office of Historic Preservation, Commonwealth of the Northern Mariana Islands. Melbourne: Department of Archaeology, La Trobe University.

Leach, F., M. Fleming, J. Davidson, G. Ward, and J. Craib. 1988. Prehistoric fishing at Mochong, Rota, Mariana Islands. Man and Culture in Oceania 4:31-62.

Lévesque, R. (compiler and editor). 1992. History of Micronesia, A Collection of Source Documents, Volume 1-European Discovery, 1521-1560. Québec: Lévesque Publications.

Lévesque, R. (compiler and editor). 1993. History of Micronesia, A Collection of Source Documents, Volume 3-First Real Contact, 1596-1637. Québec: Lévesque Publications.

Li, K. 1997. Change and Stability in the Dietary System of a Prehistoric Coastal Population in Southern Taiwan. Unpublished doctoral dissertation, Arizona State University.

Li, K. 2002. Prehistoric marine fishing adaptation in southern Taiwan. Journal of East Asian Archaeology $3(1-2): 47-74$

McGovern-Wilson, R. 1989. Afetna: The Prehistory of South West Saipan. Prepared for InterPacific Resorts and Historic Preservation Office, Saipan. Dunedin: Anthropology Department, University of Otago.

Moore, D.R. 1983. Measuring Change in Marianas Pottery: The Sequence of Pottery Production at Tarague, Guam. Unpublished master's thesis, Behavioral Science, University of Guam.

Moore, D.R. and R.L. Hunter-Anderson. 1999. Pots and pans in the intermediate Pre-Latte (2500-1600 BP), Mariana Islands, Micronesia. In J-C Galipaud and I. Lilley (eds), The Pacific from 5000 to 2000 BP, Colonisation and Transformations, pp. 487-503. Paris: IRD Editions.

Nelson, J.S. 2006. Fishes of the World. Fourth Edition. Hoboken: John Wiley and Sons, Inc.

Olmo, R.K., T. Mangieri, D.J. Welch, and T.S. Dye. 2000. Phase II Archaeological Survey and Detailed Recording at Commander, U.S. Naval Forces Marianas (COMNAVMARIANAS) Communications Annex (formerly Naval Computer and Telecommunications Area Master Station, Western Pacific [NCTAMS WESTPAC]), Territory of Guam, Mariana Islands. Prepared for Department of the Navy, Pacific Division, Naval Facilities Engineering Command, Pearl Harbor, Hawai'i. Honolulu: International Archaeological Research Institute, Inc.

Randall, R.H. 1995. Biogeography of reef-building corals in the Mariana and Palau Islands in relation to back-arc rifting and the formation of the Eastern Philippine Sea. Natural History Research 3(2):193210.

Ray, E.R. 1981. The Material Culture of Prehistoric Tarague Beach, Guam. Unpublished master's thesis, Arizona State University.

Reinman, F.R. 1977. An Archaeological Survey and Preliminary Test Excavations on the Island of Guam, Mariana Islands, 1965-1966. Guam: Micronesian Area Research Center, University of Guam. Miscellaneous Publication No. 1.

Rogers, Captain W. 1928. A Cruising Voyage Round the World. New York: Longmans, Green and Co. Spoehr, A. 1957. Marianas Prehistory. Chicago: Chicago Natural History Museum Press; Fieldiana: Anthropology Vol. 48.

Spoehr, A. 2000 (Second Edition). Saipan: The Ethnology of a War-Devastated Island. Saipan: N.M.I. Division of Historic Preservation. 
Thompson, L.M. 1932. Archaeology of the Marianas Islands. Honolulu: Bishop Museum Press. Bernice P. Bishop Museum Bulletin 100.

U.S. Naval Government of Guam 1901-1941. Annual Reports on Guam. On file at the Micronesian Area Research Center, University of Guam.

WPRFMC 2011. Pelagic Fisheries of the Western Pacific Region: 2009 Annual Report. Honolulu: Western Pacific Regional Fishery Management Council. 